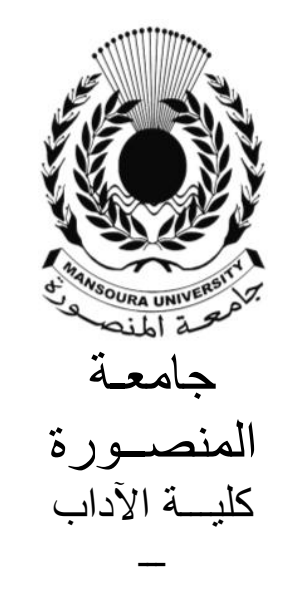

\title{
الدرس اللغوى فى شرح الكوكب المنير
}

\author{
إعـــداد

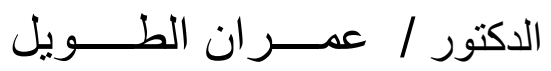 \\ أستاذ مساعد بقسم اللغة العربية الطعائ
}

كلية العلوم والآداب للبنات - النماص بجامعة الملك خالد

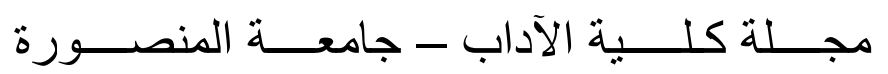

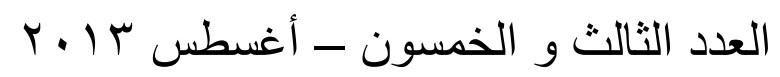




\section{الدرس اللغوى فى شرح الكوكب المنير}

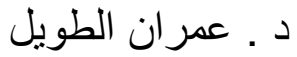

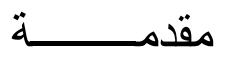

يتتاول هذا البحث بالدراسة جوانب عدة تختص فيما بين الأصوليين والنحويين

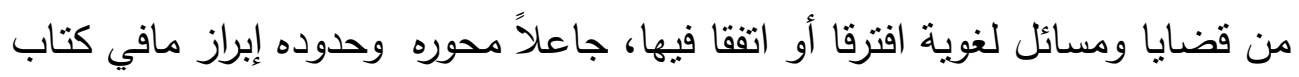

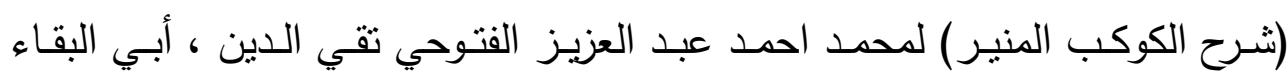

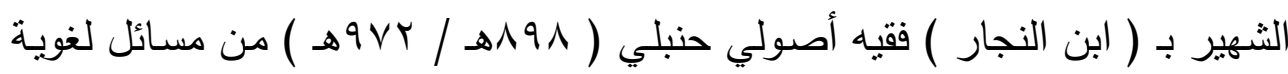
ونحوية وقد قسمنا البحث على ثلاثة فصول:

جاء الفصل الأول وقد حمل عنوان : ( في اللفظ والمعنى والوضع )ليحمل بين

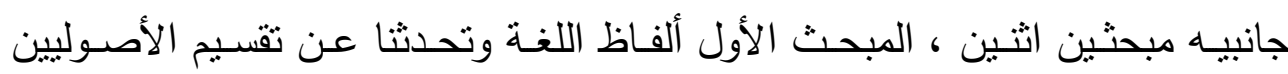

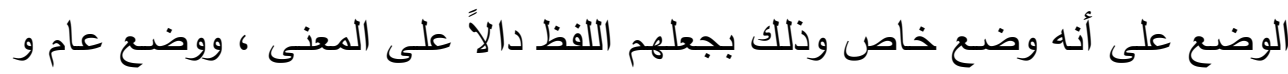

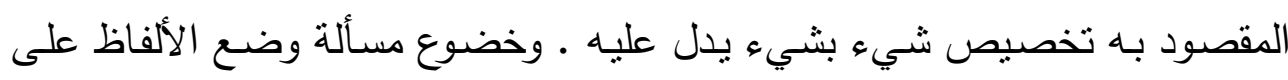

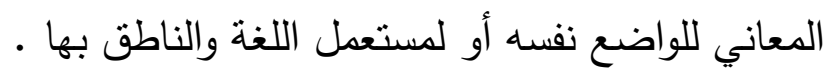

والمبحث الثناني : جعلناه في ( حقيقة الدفرد والمركب في منظور النحويين والأصوليين ، وكيفية نظر كل من الفريقين إلى المفرد والمركب ، وحقيقة فهمها وما يعنيه المفرد المركب في الدرس النحوي والدرس الأصسولي ، وتقسيمات الأصسوليين

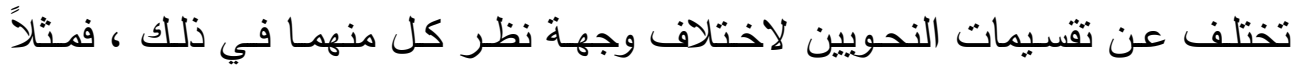
المركب عند النحوبين هو ما تركب من أكثر من لفظة واحدة منل العلم المركب تركيباً

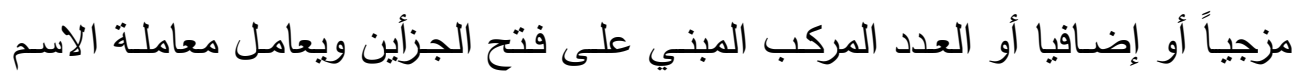

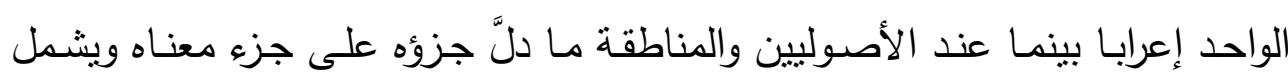

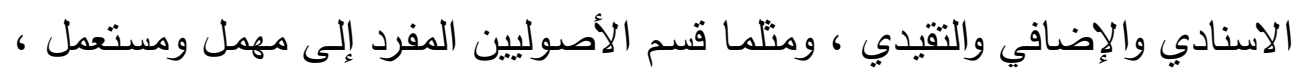
قسموا المركب التقسيم نفسه . 
على حين جـاء الفصل الثاني في الدلالـة ، مبين مفهوم ( الدال والمـلول

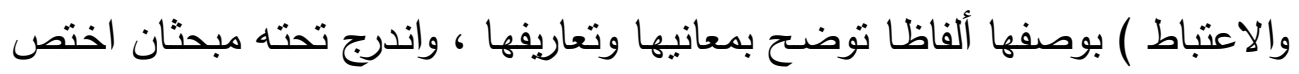

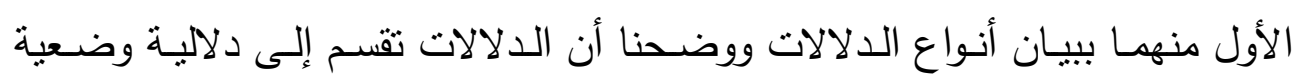

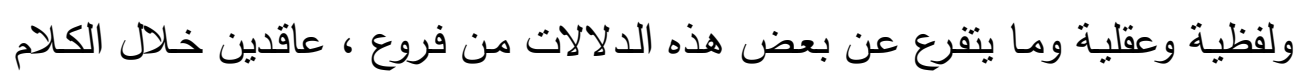

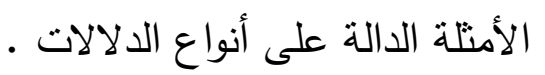
أما الثاني فقد تضمن عنوان ( الدلالة اللفظية والدلالة الاستعمالية مبينين الفرق

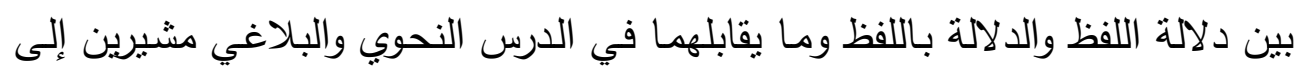

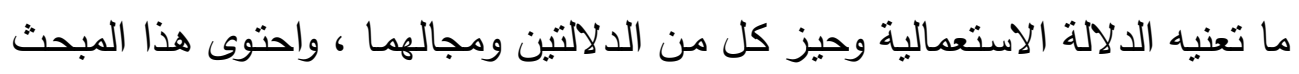
ما المقصود بهذين المصطلحين وكيف أن اللفظ هو ترجمة للصورة الذهنية فتحيل

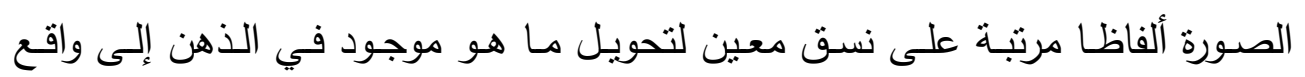

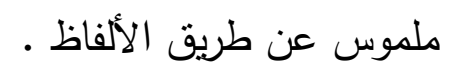

وجعل الفصل الثالث في ( التخصيص .. أركانه وأقسامه ) وبين البحث أن التخصيص يستلزم وجود ثلاثة عناصر رئيسية في هذه المعادلة ، وهي : ( المخصص ) ونعني بـه فاعل التخصيص ، و ( التخصبص ) وهو الحدث

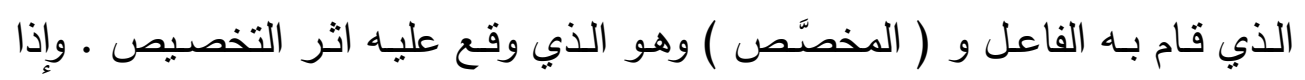

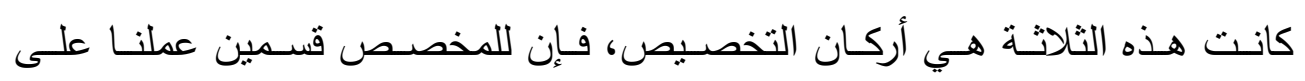

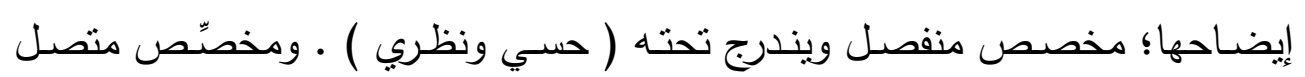

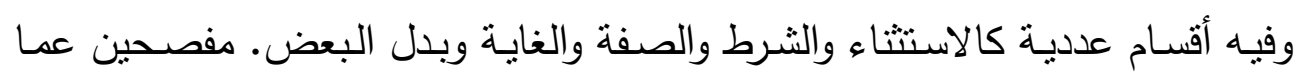

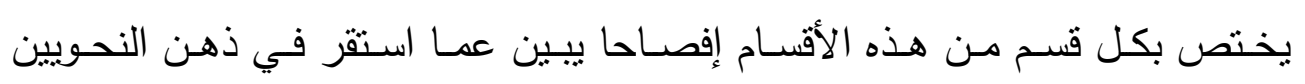
والأصوليين فيها . بكل 


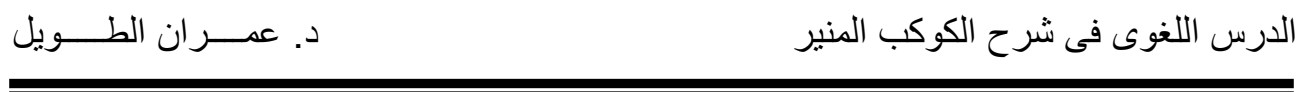

ويبقى هذا العمل من صنع البشر فما فيه من صواب فذلك بتوفيق من الله

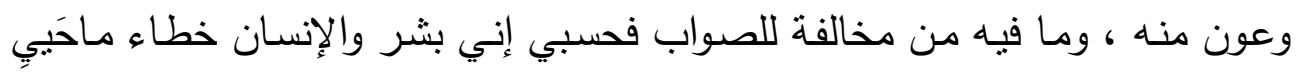

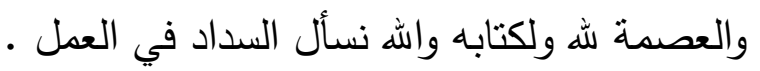




$$
\begin{gathered}
\text { في اللفظ والمعنى والوضع الأول } \\
\text { المبحث الأول }
\end{gathered}
$$

أقسام اللفظ و المعنى و الوضع بين النحويين والأصوليين

لكل لغة من لغات الأمم المختلفة تشعبات تتدرج تحت مصطلح اللغة ومن هذه

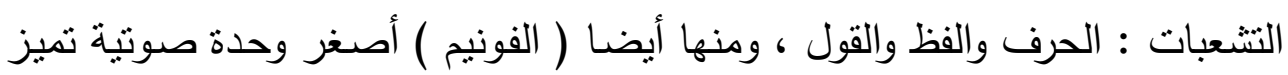
اللفظ والمعنى قد تكون عن طريق الحركة أو عن طريق حرف من الكلمة ، ومهول الكها

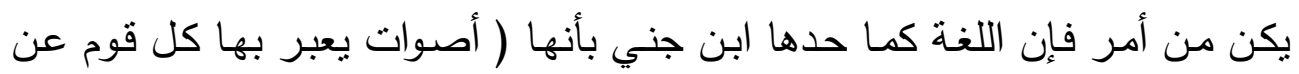

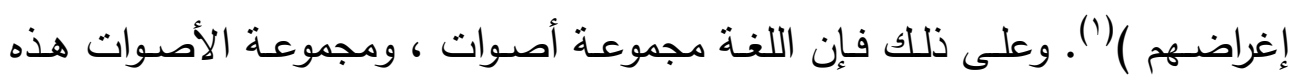
تؤلف ألفاظا ذات دلالات معينة وعلى ذلك فإن اللفظ جزء من اللغة إذ ( هو ما يتلفظ

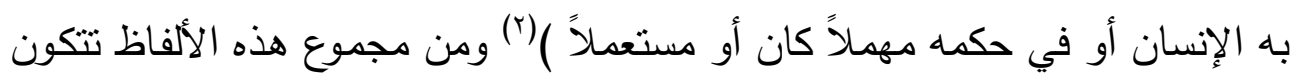

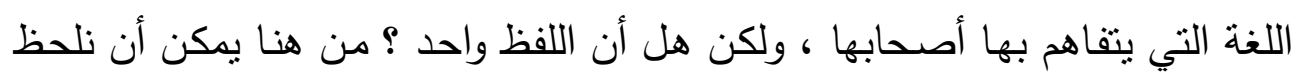

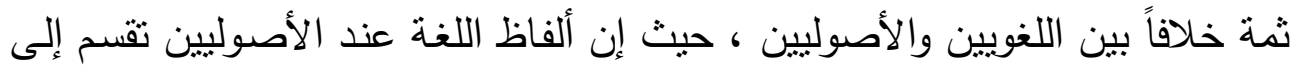

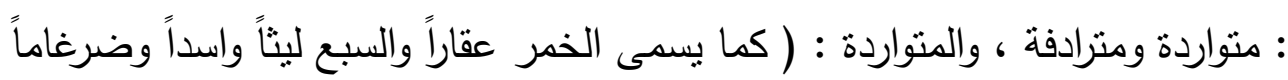

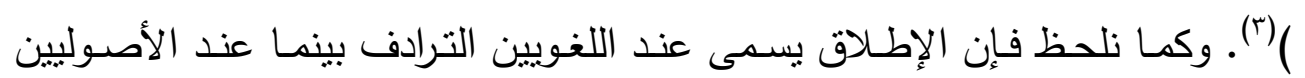

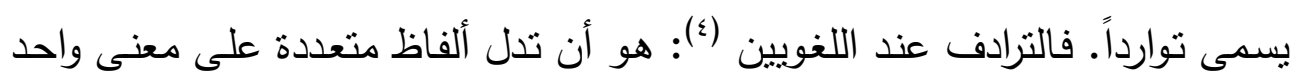

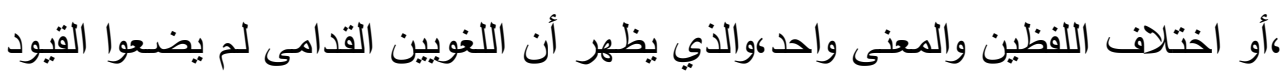

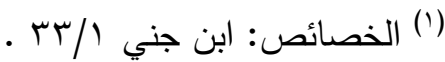

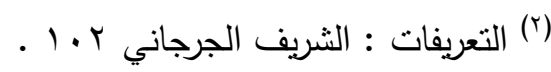

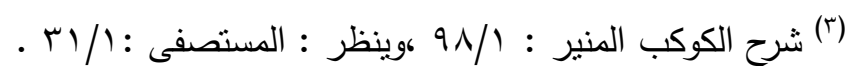

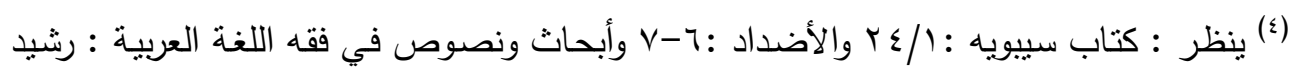

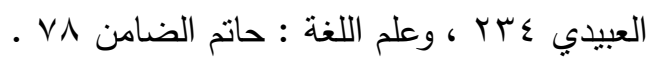




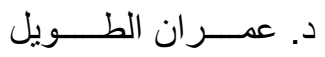

الدرس اللغوى فى شرح الكوكب المنير

والثروط التي تميز مفهوم الترادف مماقد يلتبس بـه (')بينما الترادف عند الأصوليين هو : ( أن يقام لفظ مقام لفظ لمعـان متقاربـة )(؟) وعرفه آخرون "ب الألفاظ المفردة الدالة على مسمى واحد باعتبار واحد"(") فيظهر من تعربفاتهم للترادف ولوقوعه اشتراط

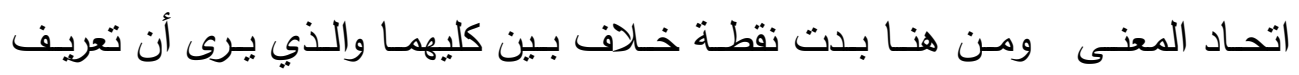
الأصــليين للترادف أكثر دقـة ووضــوحا مـن مـذهب اللغـويين والفـرق واضـح مـن التعريف (๕) (الاصؤن

وبما أن اللفظ هو الوسيلة التي بمجموع تكويناتها يتفاهم بها الإنسان مع أبناء جنسه فانه يقسم إلى ألفاظ مشتركة ووجهة نظر الأصوليين توافق وجهة نظر اللغوبين لأن اللفظ المشترك عند الأصوليين حسب ما نقله عنهم السيوطي هو : (اللفظ الواحد

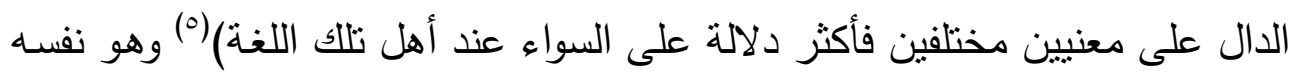
عند اللغوبين لأن الاشتراك اللفظي هو : ( أن نكون اللفظة محتملة لمعينين أو أكثر

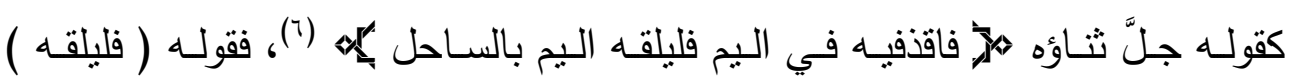
مشترك بين الخبر والأمر ، كأنه قال : فاقذفيه في اليم يلقه اليم ومحتمل أن يكون اليم

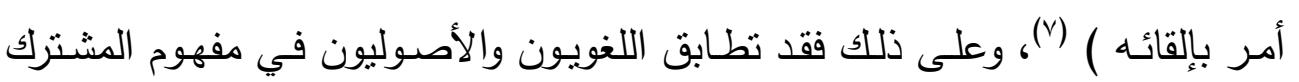
اللفظي ( اللفظ المشترك ) .وهذا بانتفاء إمكانية أن يكون المشترك قد وقع في أصل الوضع إذ قال بذلك بعض علماء الأصول مثل الفخر الرازي والأسنوي عند تعريفهم

' بنظر : الترادف في القرآن الكريم بين النظرية والتطبيق : •؟r.

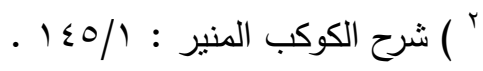

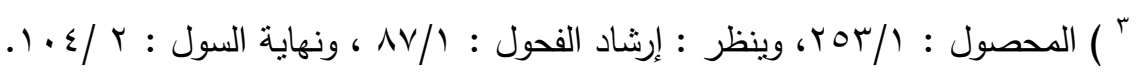

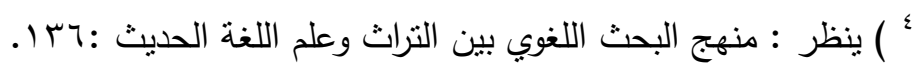

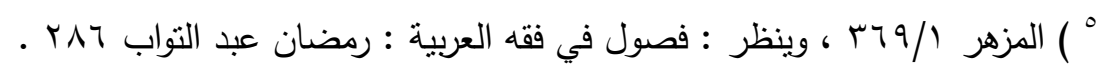

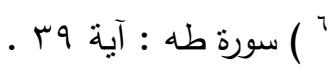

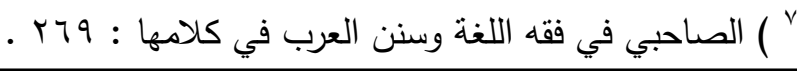


للفظ المشترك بأنه : اللفظ الموضـوع لحقيقتين أو أكثر (').ولا يكون ذلك في أصل الوضع لأنه سيؤدي إلى الغدوض واللبس على حد قول ابن درستوبه (؟). كذلك يقسم اللفظ إلى لفظ عام مطلق عند الأصوليين ويسمى لفظ مستغرق وهو اللفظ الذي يساعد على إيصال دلالات متعددة بحيث يدخل فيه جانب المجاز وهو : ( اللفظ الذي يدل حسب وضـعه اللغوي على شـوله واستغراقه لجميع الأفراد التي يصدق عليها معناه من غير حصر في كمية معينة منها فلفظ ( كل عقد ) في قول الفقهاء ـ كل عقد يشترط لانعقاده أهلية العاقدين لفظ عام يدل على شمول كل مـا يصدق عليه أنه عقد من غير حصر في عقد معين أو عقود معينة )(ז). وهذا هو الاستغراق في عمومية اللفظ من حيث انطباقه على ما يندرج تحته ، كذلك قسم اللفظ

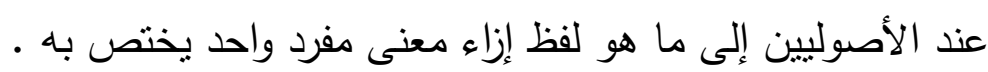
وإذا كان اللفظ عند اللغوبين والنحوبين على مـا مـرّ ذكره فانـه يقترب عند الأصوليين من هذا التعريف في المعنى لأن اللفظ عندهم ( صوت تعتمد على بعض مخارج الحروف لان الصوت لخروجه من الفم صار كالجوهر المرمي منه فهو ملفوظ ) (ء) وهذا المفهوم الاصطلاحي للفظ ينطبق على مفهومه اللغوي لان اللفظ لغة هو الرمي أي رمي الثيء فصار ذات دلالة واحدة وهو ما ذهب إليه اللغويون والنحويون

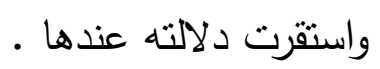

على حين أن القول لغةً هو مجرد النطق ليس شرطاً أن يؤدي معنى ـ أما في

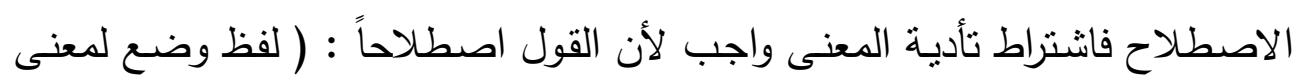

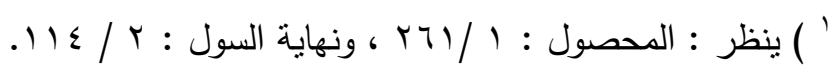

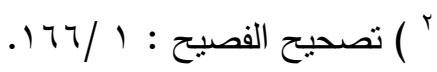

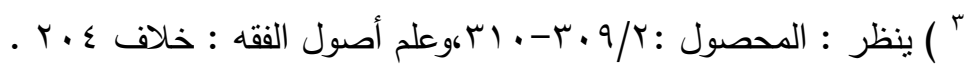

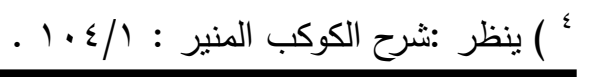


ذهني ) (') أي أن القول نرجمة لفظية لصورة تكونت في الذهن طورت هذه الصورة من المعنوي إلى الحسي فانتقلت من الذهن إلى اللسـان وصدرت عن طريـق ألفاظ استطاعت أن تعبر عن تلك الصـور الذهنيـة أو المعنى الذهني وان لـ تلم بأطرافه والقول على ذلك يقابل مصطلح التركيب في اللغة والنحو ، واللفظ اشمل من القول لان اللفظ يندرج تحته مـا هو مهـل ( الذي لا يؤدي معنيً مفيداً ) ولذلك أخرجته العرب من لسانها وما هو ( مستعمل ) أي يؤدي معنى مفيداً ، ولذلك كان مدار لسان

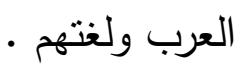

والعلماء مختلفون في مصطلح ( وضـع لمعنى ) وهم على ثلاثة فرق مقسمين المعنى إزاء ذلك منهم يجعلونـه معنى قـائم في الذهن ويستوي في ذلك أن القول الموضوع لهذا المعنى الذهني يطابق ما في الخارج أو لا يطابق ، أو أن القول وضع دهع للمعنى الموجود في الخارج وفق دلالة ذهنية تتطبق على ما في الخارج من سمات توحد القول أو في بعضه وان القول موضوع للمعنى من حيث هو معنى دون الالتفات إلى ما هو موجود في الخارج وهذا على ما نظن الاعتباط الذي قال بـه ( سوسير ) حين تحدث عن العلاقة بين الدال ( القول واللفظ ) والمدلول (المعنى ) وما بينهما ( الاعتباط ) ومفهوم الاعتباط ليس كما يفهم الآن (r).

أما الوضع فقد قسمه الأصسوليون إلى قسمين : وضـع خاص وهو الذي تعارفوا عليه من حيث ( جعل اللفظ دليلاً على المعنى )(r) أي أن هنالك علاقة بين اللفظ

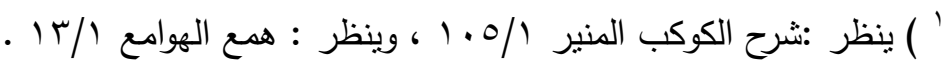

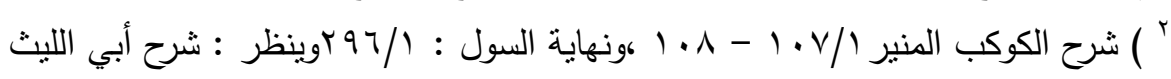

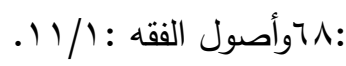

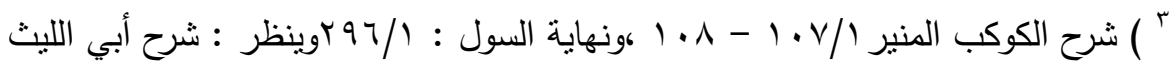

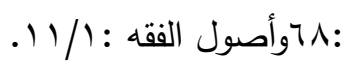


والمعنى هذه العلاقة هي التي دفعت إلى إطلاق هذا اللفظ على هذا المعنى دون سواه

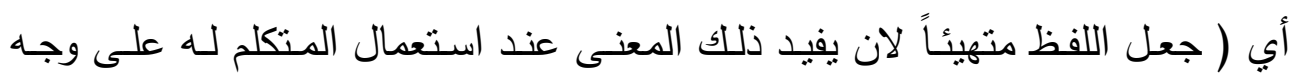
الخصوص ) بمعنى أن اللفظ لا يستعمل إلا للالالة على معنى معين لا يجاوزه كلفظ ( قرآن ) فإن دلالة هذا اللفظ أو أن وضع هذا اللفظ ليفيد معنى الكتاب المقدس الذي لإني

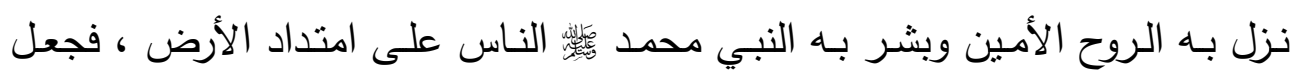

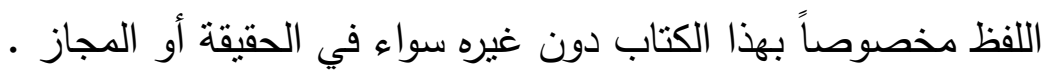

ووضـع عـام : والعموميـة هنـا يقصــــــــا تخصـيص لفظظ موضـوع بمعنى مخصوص مدلول عليه بـاللفظ أو ( تخصيص شـيء بشـيء يـل عليه )(') ويدخل ضمن ذلك المقادير المعينة لان المقادير تدل على مقدراتها أي تدل على مقدار معين اعتمل واستقر في عرف الناس كلهم كالكيل والوزن والمساحة والقياس والعدد، وفي كلتا الحالتين ( الوضع الخاص والعام ) فإن مسألة وضع الألفاظ على المعاني للدلالة

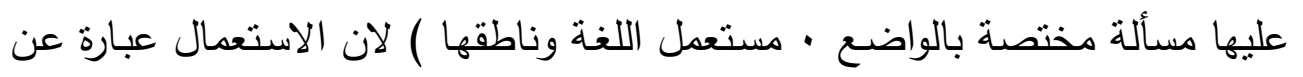
معنى في الذهن ولفظ مطلق على ذلك المعنى فيكون المعنى روحاً واللفظ جسداً لتأدية المعنى المستوفي في الذهن ووسيلة للإفهام فالاستعمال اللغوي هو ( إطلاق اللفظ وإرادة المعنى ) وهذا الاستعمال يسمى في الدرس اللغوي ( أصل الوضع ) أي أصل فيل الاستعمال ويقابله مصطلح الحقيقة وربما يراد بإطلاق اللفظ على غير معناه الحقيقي لوجود علاقة مشـابهة معينـة بين المعنى الأول والمعنى الثاني وهذا يسمى المجـاز واللجوء إلى إطلاق اللفظ على سبيل المجاز على معنى آخر غير الحقيقي لوجود

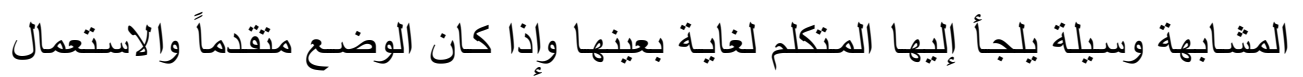
لاحقاً فإن الحمل على المعنى هو مرتبة منتأخرة عنها لان تحميل اللفظ معنى آخر غير الحقيقي هو حمل على وجـه المجاز أي مجـاوزة استعمال حقيقة اللفظ فتأديـة

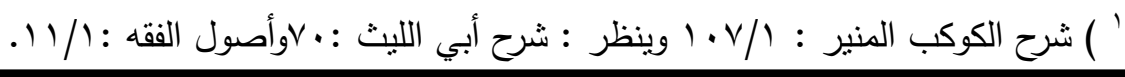


معنى آخر أو حمل اللفظ على أن يؤدي دلالة أخرى غير الحقيقية مجازاً غايـة من غايات المنكلم للوصول إلى معنى يريده . المبحث الثاني المفرد و المركب في منظور النحويين والأصولبين تتاولنا في المبحث المتقدم تعربف اللغة وأقسام ألفاظها كذلك تعرضنا لدراسـة مصطلح اللفظ والقول وما قاله علماء الأصول في ماهية المعنى وإذا كانت اللغة تقمم إلى ألفاظ يؤدى بها المعنى فإن هناك تقسيماً ثانياً للغة يتجسد في أن اللغة نوعان ('): مفرد ومركب وهنا نجد أن التقسيم في المبحث السابق للغة قائم على أساس المعنى ، أمسا تقسيم اللغة في هذا المبحث فيقوم على أسـاس ملاحظة اللفظ من حيث الإفراد والتركيب فالمفرد والمركب في الدرس النحوي واللغوي اقرَّ بهما لورودهما عن العرب أي أن العرب تكلمت به وجعلته في لسـانها وإليه يذهب صساحبنا بقوله : ( أما المفرد فلا نزاع في وضع العرب له وأما المركب فالصحيح أنه من اللغة وعليه الأكثر ) (؟)، وعلى ذلك فإن التركيب واقع في لغـة العرب ، ولكن مـاذا نعني بـالمفرد وماذا نعني بالمركب ؛ المفرد في الدرس النحوي نعني به(؟): الكلمة الواحدة سواء أدت معنى أم لم تؤد، ويشمل الاسم والفعل والحرف أمسا عند المناطقة والأصوليين فإن المفرد يشترط فيـه تأديـة معنى وهم بذللك يخرجون الحرف من دائرة الإفراد كذلك يشترطون بأن لا جزء لذلك اللفظ دال على المعنى الموضوع فهم يقيدون المفرد بمعناه ولا يدل جزء

$$
\begin{aligned}
& \text { ' ) ينظر : شرح الكوكب المنير : 1 / 1. 1. }
\end{aligned}
$$

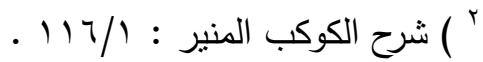

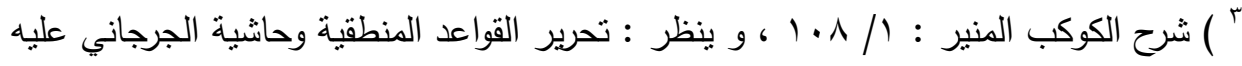

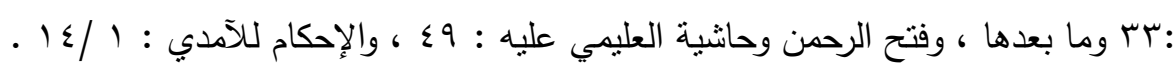


المفرد على جزء المعنى أو كله وجعلوه على أربعة أقسام(') : أولا : ما لا يجزأ مطلقاً

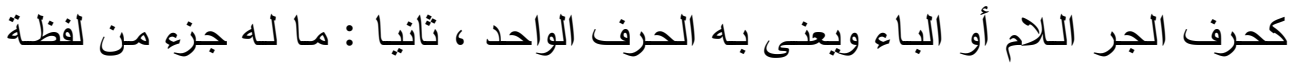

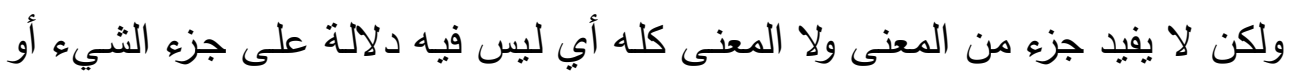

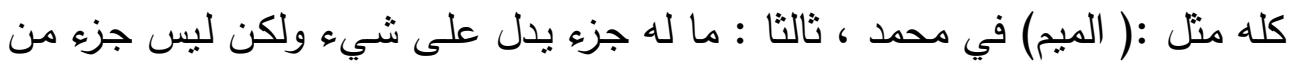

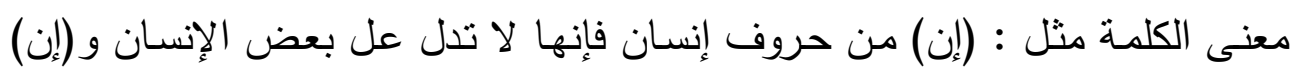

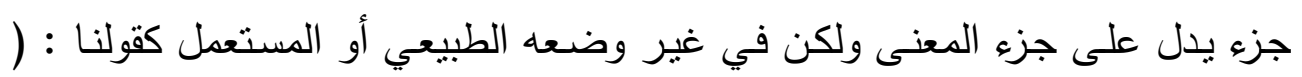
حيوان ناطق علما على شخص ) وهو ينطبق على أي شخص ولئ رجلاً كان أو امرأة

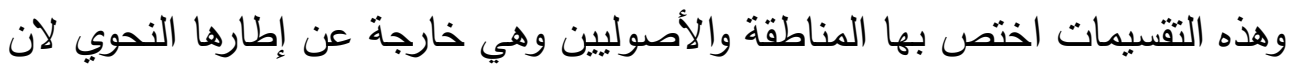

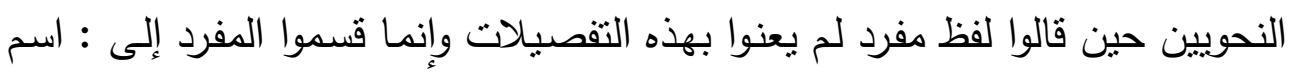

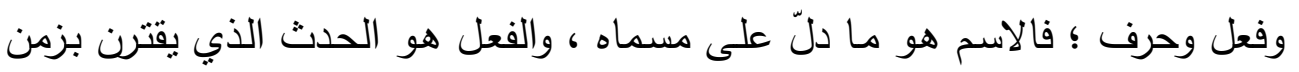

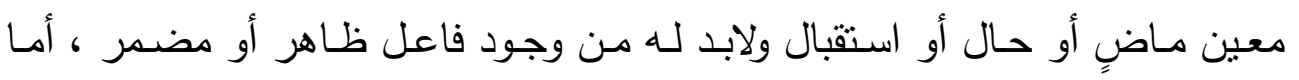

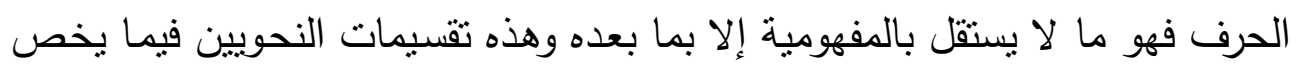

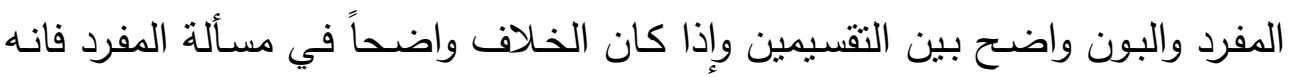

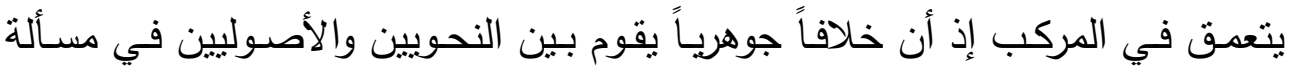
التركيب ، لان المركب عند النحويين هو ما تركب من أكثر من كلمة ويشمل تحت

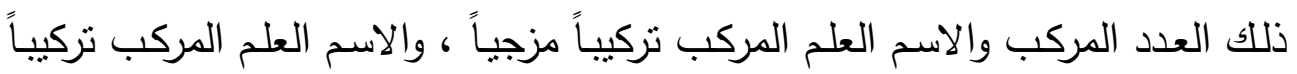

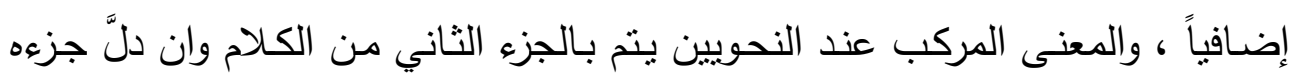

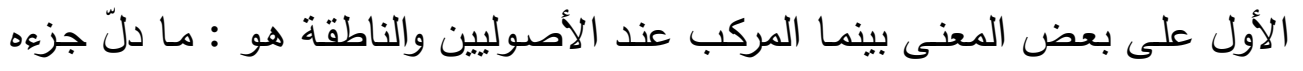

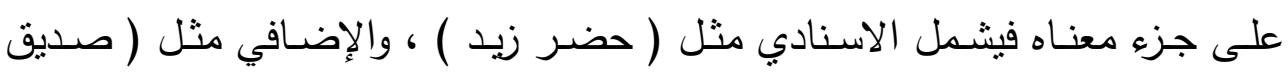
محمد ) ، والتقيدي مثل (للطالب الحق ) وهذا التعريف عند المناطقة والأصوليين

' ) شرح الكوكب المنير : ( / . 1 ، و ينظر : تحرير القواعد المنطقية وحاشية الجرجاني عليه

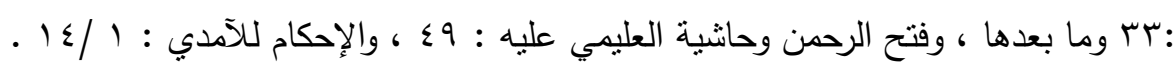




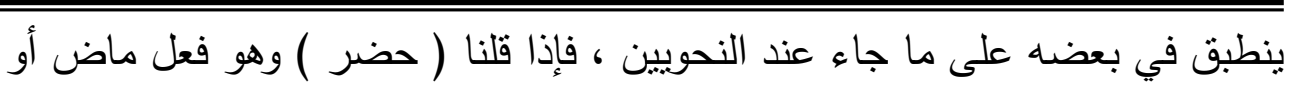

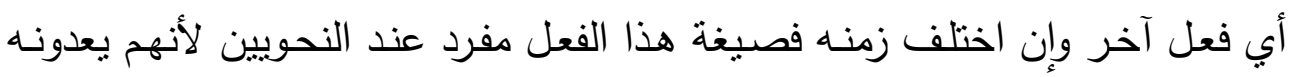

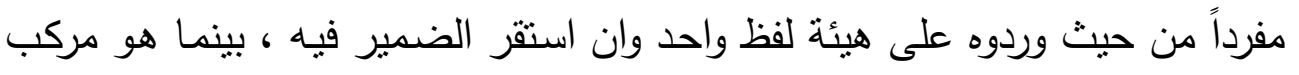
في رأي المناطقة والأصـوليين فالفعل المضارع ( يحضر ) مركب هنب عندهم لأن الياء

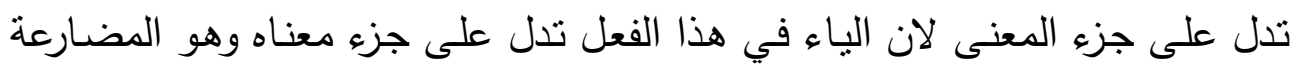

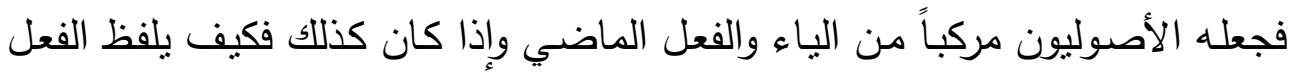

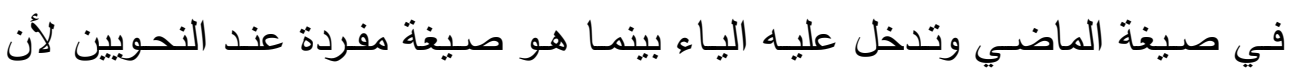

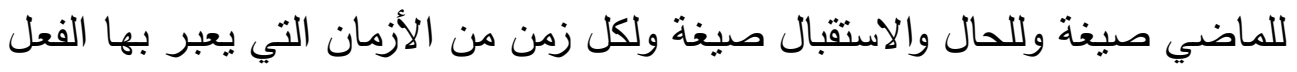

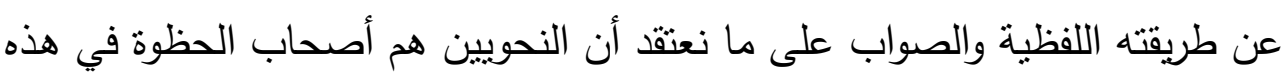

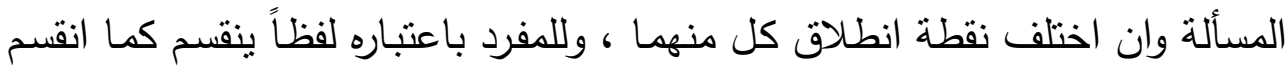

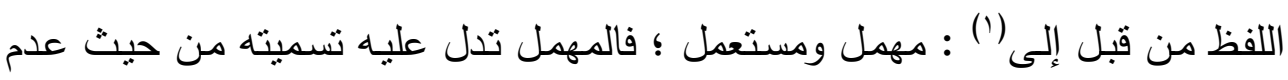
تأديته دلالة معينة لأنه قاصر على ذلك ويشمل حروف الهجاء في اللغة لأن مدلولات

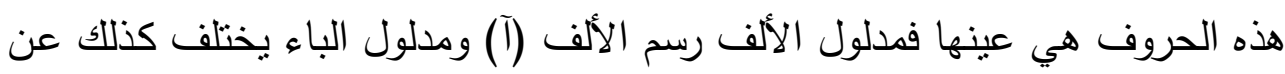

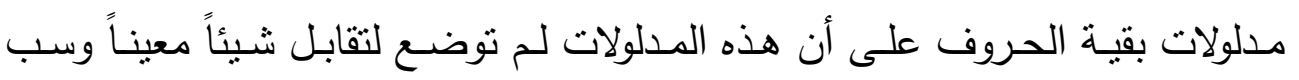

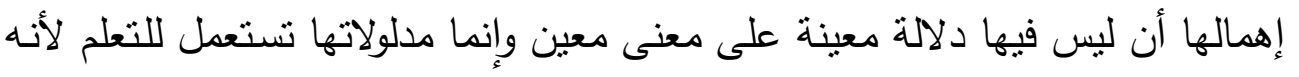

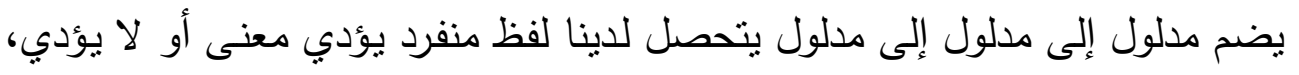
وقسم آخر مستعمل والمستعمل إن استقل بمعناه، فإن دل بهيئته على زمن من المن الأزمنة

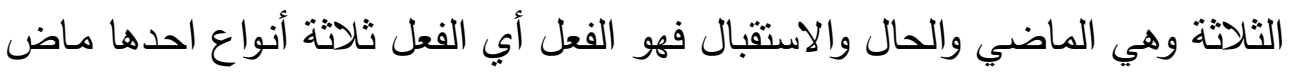

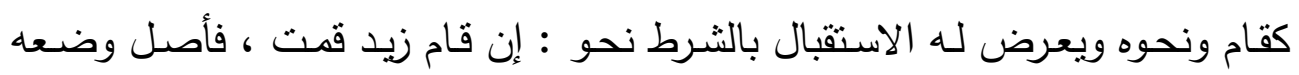

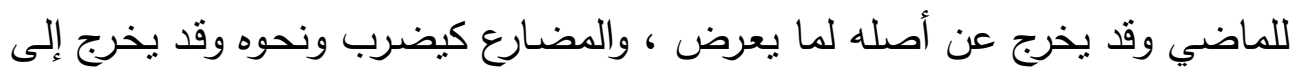

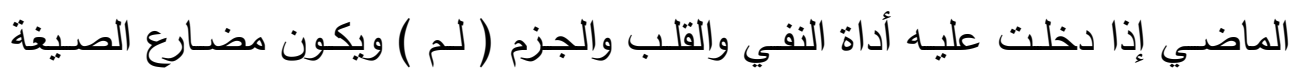

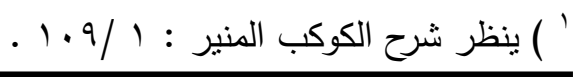


ماضي الزمن كقولنا لم يضرب عمروُ زيداً مـع انها موضوع للحال والاستقبال بدلالة إعرابه وقد يخرج عن أصله لما يعرض اللفظ ، والأمر كاضرب ؛ وهذه كلها فواصل مايز بينها النحويون في معرفة الأفعال وأزمنتها وان كان هذا فيما يخص الفعل من حيث الدلالة بالزمن فإذا تجرد المفرد المستعمل عن عنصر الزمن فهو الاسم الذي مئي يدل على معنى وهيئة منل: ضارب ؛ فهذا اللفظ يفيد معنى الضرب وهيئة الضارب ولكنه لا يفيد المتلقي بزمن الضرب مدب مستب

إلا بقيام قرينة لفظية تحدد الضرب في الماضي أو الحال أو الاستقبال وإذا كان

اللفظ المفرد المستعمل يفيد الزمن والحدث معاً وهو الفعل بأزمنته الثلاثتة أو يفيد المعنى والهيئة بخـلاف الزمن هو الاسم فإن هناك عنصراً ثالثناً في الجملة لا يفيد

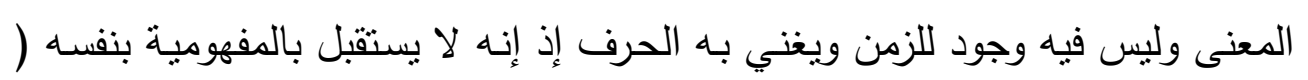

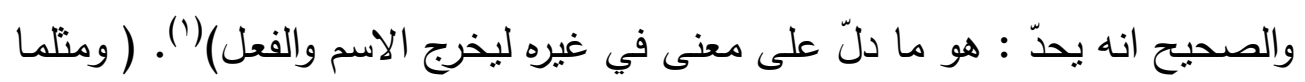
يقسم المفرد إلى مستعمل ومهمل فيرى الأصوليون أن المركب يقسم التقسيم عينه أي قسم مهمل وهو موجود ومنلكوا لله بـ ( الهذيان ) فانه لفظ مدلوله لفظ مركب مهمل والأشبه انه غير موجود لان الغرض من التركيب (الإفادة)(ז) واستشلوا بهذا على أن

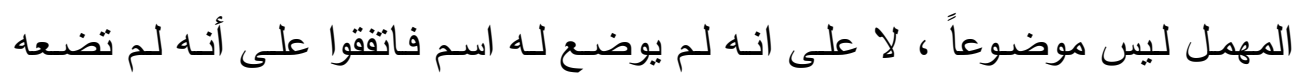

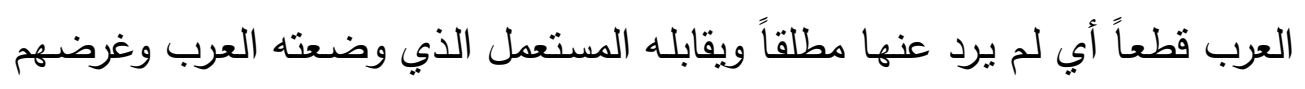
الإفادة المعنوية المتحققة في استعماله واستدلوا على صحة الوضع بوجود قوانين في الكلام العربي لا يجوز الحياد عنها وحتى ما خولفت هذه القوانين أطلق عليها أنها غير عربية وهم يعنون في ذلك العلاقة بين المتلازمين ، ففي العربية لا يجوز تقديم

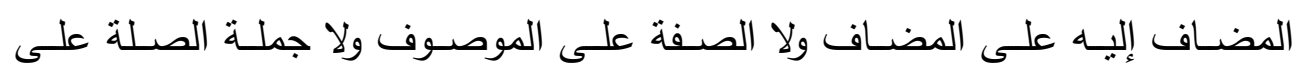

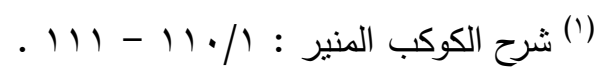

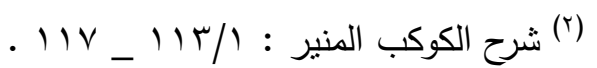




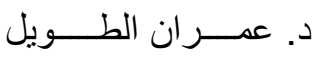

الدرس اللغوى فى شرح الكوكب المنير

الموصول مـع البقاء على المعنى نفسه وذلك غير جائز في العربية لأن مثل هذا التقديم لما حقه وجوب التأخير ، والتأخير لما حقه وجوب التفاء ودئ التقديم يسمى خرقاً للقانون

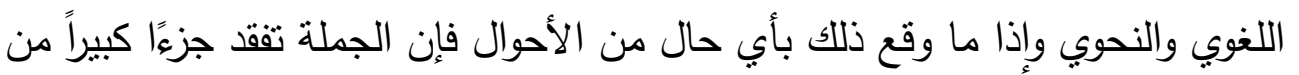

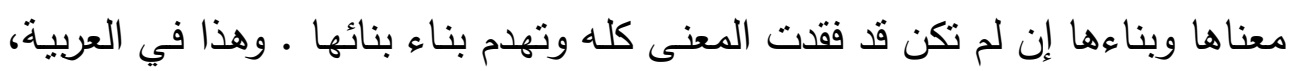

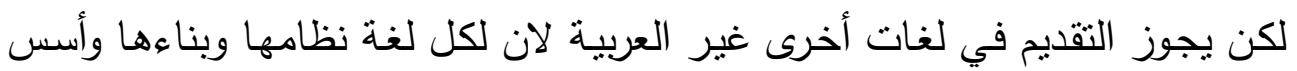
رصف ألفاظها .

$$
\begin{aligned}
& \text { الفصل الثاني } \\
& \text { الدلالة، مفهوم الدال و المدلول } \\
& \text { المبحـث الأول } \\
& \text { أنــــــواع الــــــــلالات الـات }
\end{aligned}
$$

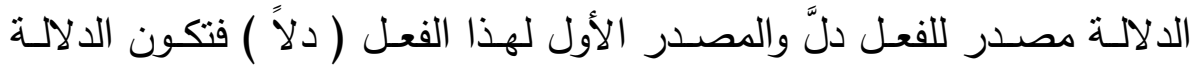

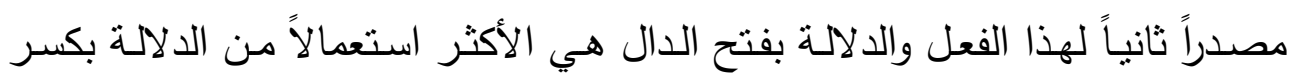

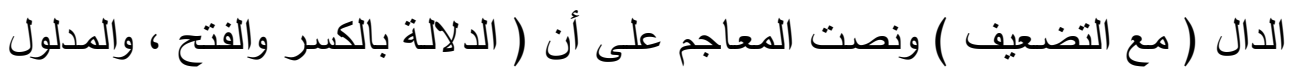


والدليل ـ قال سيبويه والدليل (') علمه بالدلالة ورسوخه فيها .. والدالٌ الذي يجمع بين البيعين ، والاسم الدالة بالفتح والدالة للاليل أو الدلال ـ قال ابن دريد : بالفتح عرفت الدلالة ، ودليل بين والدلالة بالكسر لا غير )(؟) وعلى ذلك فإن الاستعمال الأفصح لهذا المصدر هو الدلالة وتشير التعاريف المتقدمة إلى فحوى الدلالة والمقصود بها : ( ما يلزم من فهم شيء فهم شيء آخر )(r) فالثيء الأول هو الدال والثيء الثاني هو المدلول عليه (؛)، وعلى ذلك يترتب أننا نفهم شيئًا ثم نفهم شيئاً آخر من الثيء الثيء الأول لأنه يقتضيه وذهب بعضهم إلى أن الدلالة هي : ( دراسة المعنى أو العلم الذي يدرس المعنى أو ذلك الفرع الذي يدرس الثروط الواجب نوافرها في الرهز حتى يكون

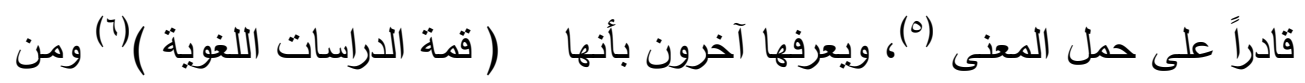
هذين التعريفين يتضح لنا أن الدلالة عند بعض اللغوبين أعم من المعنى والعلاقة بين

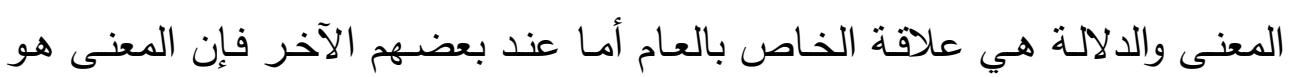
الدلالة والدلالة هي المعنى ('). والدلالـة المطلقـة ثلاثة أنـواع : الأول مـا دلالتهه وضـعية ويتضـح معنى هذه

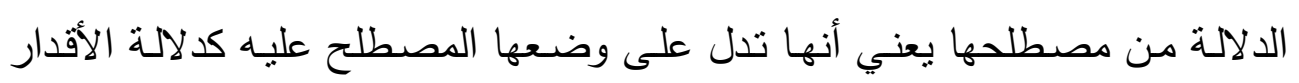
على مقـدراتها ومنـه دلالـة السـبب علىى المسبب كالمـدلول على وجـوب الصــلاة والمشروط على وجود الثرط كالصلاة على الطهارة وإلا لما أصبحت . والنوع الثاني :

$$
\begin{aligned}
& \text { (1) ينظر : تعريف ( الدليل ) في التعريفات }
\end{aligned}
$$

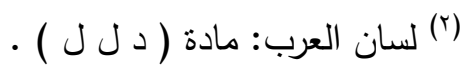

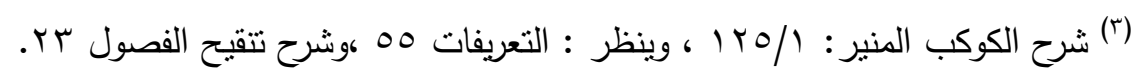

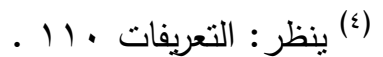

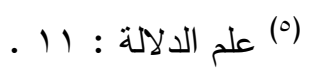

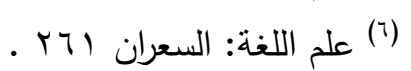

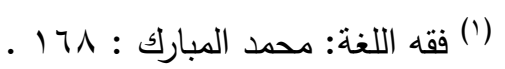


ما دلالته عقلية وهو الذي يثبت دلالة وجود العالم لإثبات وجود جوهر هذا العالم ( الله عز وجل ) فلولا الاستـلال بالفعل عن طريـق برهنه وجود مـا في هذا العـالم من مخلوقات من طبيعيـة ومن جوامد ومتحركات وعلامـات تدل على منشئ هذه كلها فنستدل بالعقل بوجود الله فلابد لهذا العالم من سلطان ـ النوع الثالث ما دلالته لفظية أي ما يؤديه اللفظ من دلالة أولى أو ثانية ولذلك تضيف ضمن الدلالة اللفظية ثلاثة أقسـام : دلالـة طبيعيـة كدلالـة التأفف على الضـجر والتحسف على الندامـة والتحسر على الألم ويمثل لها صاحبنا بدلالة ( آخ على وجع الصدر ، أو وجع شيء آخر )(ז') ودلالة عقلية كدلالة الصوت على حياة صاحبه ، ودلالة انقطاع النبض على وفاة الشخص ، ودلالة حركة الشخص على تمتعه بالصحة ، والدلالة الوضعية وهي القسم الثالث من أقسام الدلالة اللفظية ، ومسألة الوضع في اللغة تدور في الفلك البلاغي لأننا نقول أصل استعمال اللفظ أو التركيب بمعنى هو أول استعمال له على اللسان وفي الوقت نفسـه ثباته في ذهن جميع المتكلمين مـن أصـحاب تلك اللغـة والدلالـة

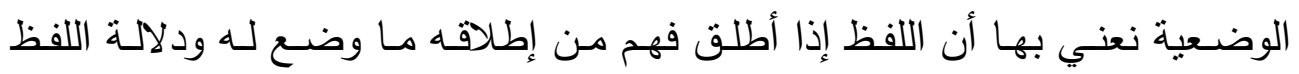
الوضـعية على مسماه أي يسمى ذلك اللفظ هي دلالـة مطابقة (r)، أي مطابقة اللفظ للمعنى والمعنى للفظ في حقيقـة الاسـتعمال كدلالـة الإنسـان على الحيـوان النـاطق والنطق هو الذي يفرق بينهما فحين تقول حيوان يتبادر إلى الذهن الحيوان وهي دلالة وضعية متعارف عليها ، وحين تقول حيوان ناطق يقفز إلى الذهن الإنسان لأنه يفرق على الحيوان بالنطق وقد أطلق عليها دلالة مطابقة ؛ مطابقة اللفظ للمعنى لأن اللفظ مطابق لتمام المعنى الذي وضـع له ، فاللفظ موافق للمعنى لأنها وضـع لـه ، فعندما نقول شجرة ، ترسم في الذهن صورة الشجرة المزروعة ولا يرسم شيء غيرها وهذه من

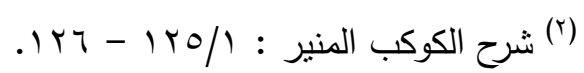

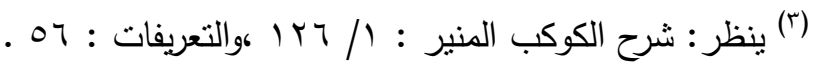


دلالة المطابقة فدلّ اللفظ على المعنى دلالة كاملة مطابقة لما في الذهن ، ( وعلى هذا فالد لالة هي إثارة اللفظ للمعنى الذهني أي مدلوله ، وبين اللفظ والمعنى في كل

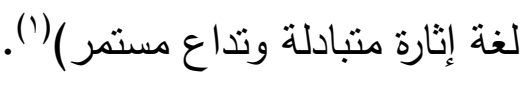

$$
\text { المبحث الثاني }
$$

الدلالة اللفظية و الدلالة الاستعمالية ( باللفظ )

تتاولنا في المبحث السابق حد الدلالة وأنواعها وما يتفرع عن بعضـها ، ومحور هذا البحث الحديث عن دلالة اللفظ والدلالة باللفظ وهنالك فرق واضـح بين استعمال المصطلحين المـكورين ، إذ إن العـرب جعلت مـن معـاني حرف البـاء الاستعانة ، فدلالة اللفظ مفرداً أو مجموعاً مفهوم لأننا حين نقول فلان شجاع فذلك دليل على أن الشجاعة مقترنة به فهو شجاع والثجاعة صفة فيه ولكنا حين نقول : فلان أسد فلا يعقل إنه أسد على وجه الحقيقة لأن الفرق بين الاثتين واضـح من حيث الجنس ؛ فـالأول حيوان نـاطق والثاني ليس كذلك ولأن الأول لا ينزل منزلة الثاني في الهيئة 


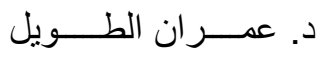

الدرس اللغوى فى شرح الكوكب المنير

وكذلك الثاني لا ينزل منزلة الأول في الهيئة وإنما هناك صفة اشنرك فيها فلان والأسد وهي الثجاعة أو القوة ، وهذا المثال الثاني هو دلالة باللفظ وليس دلالة لفظ أي دلالة بالاستعانة بلفظ للالالة على معنى آخر فيستفاد معنى الثجاعة من الاستعانة بلفظ الأسد ، فصار المثال الأول دلالة لفظ والثاني دلالة باللفظ وعلى ذلك فدلالة اللفظ هي معلى اللى معنى اللفظ سواء أكان مفرداً أم مضموماً إلى غيره في التركيب أو هو مفهوم اللفظ وهو معناه الأول الذي يرسخ في ذهن المتكلم والسامع المتلقي ويمكن أن نطلق عليه

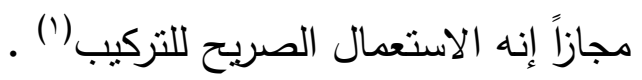

أمـا الدلالـة بـاللفظ فتعني أن استعمال المتكلم لنمط معين من اللغـة يفهم منـه المعنى السـاكن خلف هذا الاستعمال بعد المرور بالمعنى الأول ويتمكن المتلقي من معرفة مراد المتكلم لاستعماله هذا اللفظ لتأدية الدلالة المعنية والمقتضية لمعنى معين

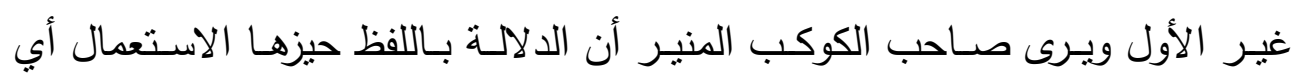
استعمال اللفظ في موضوعه الأول على وجه الحقيقة أو الاستعمال الموجود في ضم

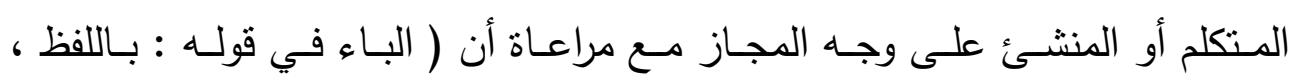

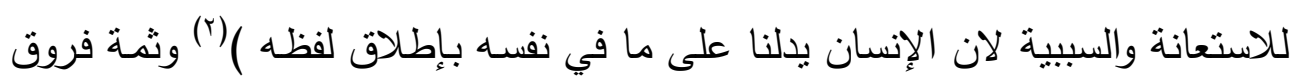
معينة بين دلالة اللفظ والدلالة باللفظ ، وتتعين هذه الفروق من الآتي نصدان(آ) : ا. من جهة المحل ؛ فإن محل دلالة اللفظ القلب ومحل الدلالة باللفظ اللسان . r.. من جهة الوصف ؛ لان دلالـة الوصف صفة للسـامع بينما الدلالـة بـاللفظ هي

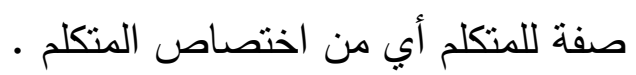

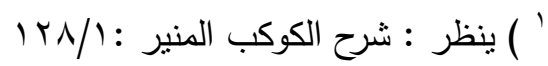

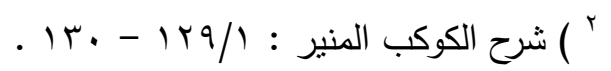

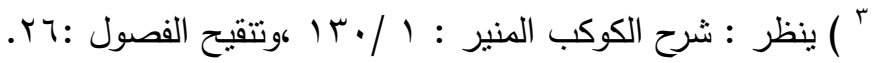


r. من جهة السبب ؛ لان الدلالة باللفظ مسبب بينما دلالة اللفظ مسبب عنها . ؛. من جهة الوجود ؛ فأينما وجدت دلالة اللفظ وجدت الدلالة باللفظ ولا يجوز العكس

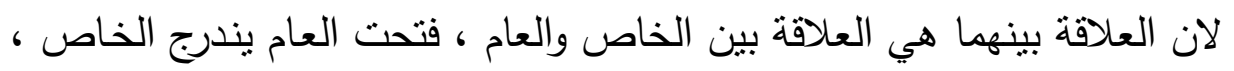
والعام يشمل سمات العام والخاص ، بينما الخاص يشمل جزء من سمات العام .

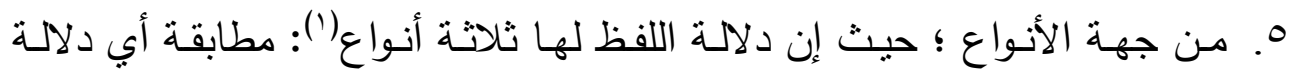

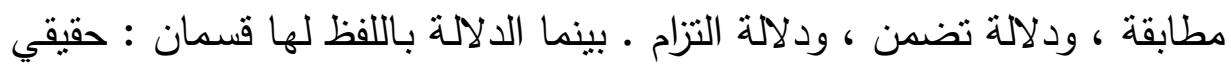

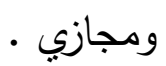

المنطوق و المفهوم

( المنطوق هـو مصـلح يسـتعمل في اللغـة وأكثر مـا بسـتعمل في مجـال

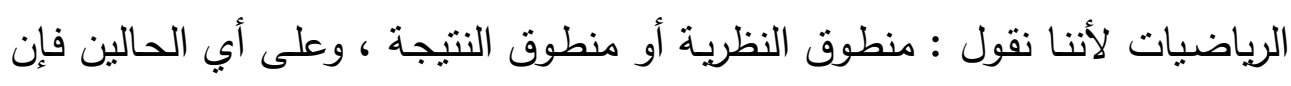

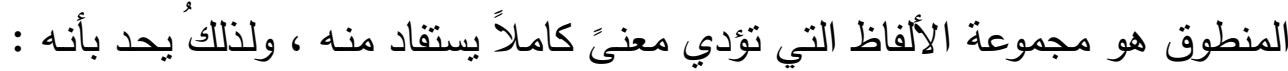

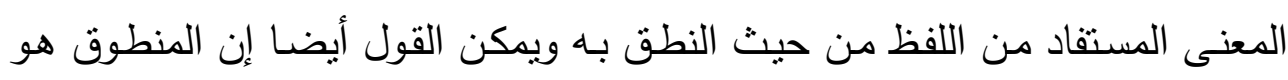

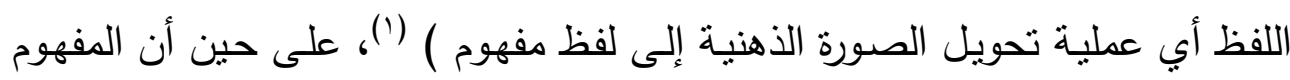

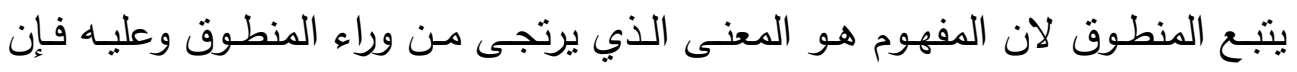

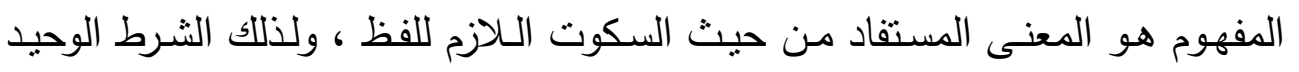
لتحقيق لفظ المفهوم وهو تحقق الفائدة والمفهوميـة مـن اللفظ المنطوق وهو الفهم المتحصل من وراء ذللك اللفظ ويقابله في الدرس النحوي ( المفيد فائدة يحس السكوت

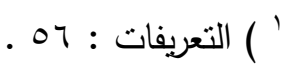

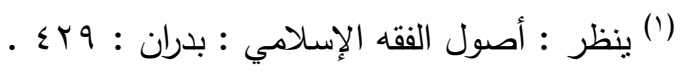


عليها ) فصار المنطوق في اللغة يقابل الكلام في عرف النحاة ، والمفهوم في اللغة يقابل الفائدة التي يحسن السكوت عليها عند النحاة ، وعلى هذا فإن دلالة اللفظ تقسم على قسمين : المنطوق والمفهوم ؛ والمنطوق كما بان مما تقدم ما يدل على معنى معين مـن وراء لفظ معين • والمنطوق قسمان : منطوق صـريح وهو الذي يقابل

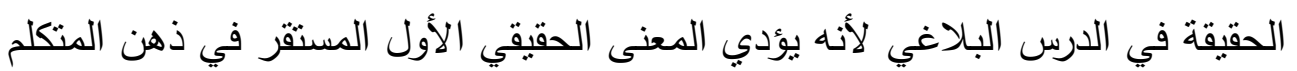

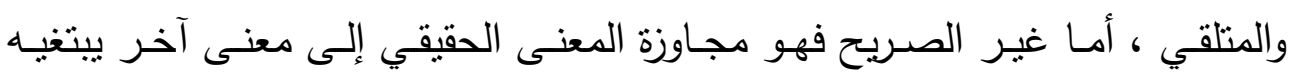
المتكلم ويفهمه السامع وتسمى هذه الدلالة دلالة التزام بتأدية معنى معين من وراء هذاء لهاء

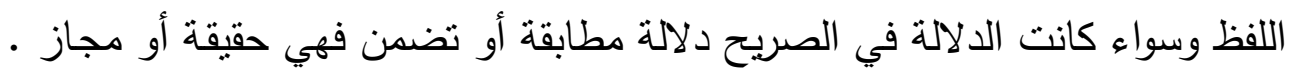
وتقسم دلالة الالنزام على ثلاثة أقسام :

دلالة اقتضاء وإثارة وتتبيه لأن المعنى قد يقصده المتكلم ويتضمنه ما يصدق

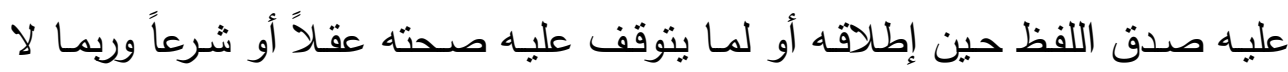

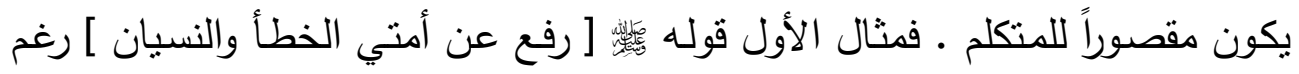
أن الخطأ والنسيان لم يرفعا ولذلك يتضمن ما يتوقف عليه الصدق من الإثث والموآخذة المانة

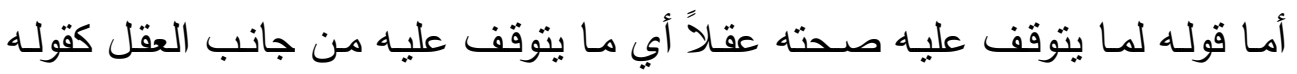

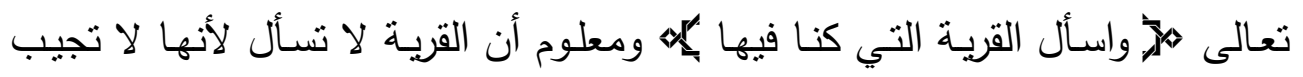

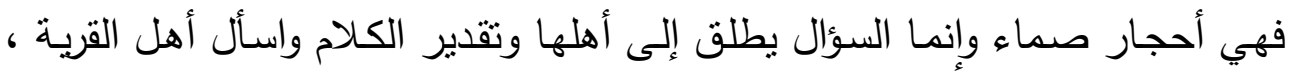

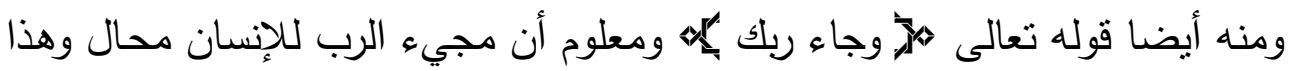

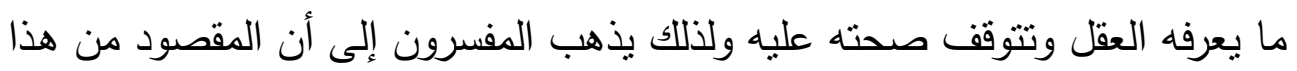

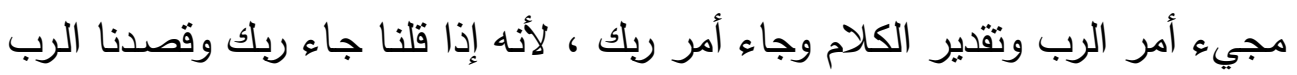

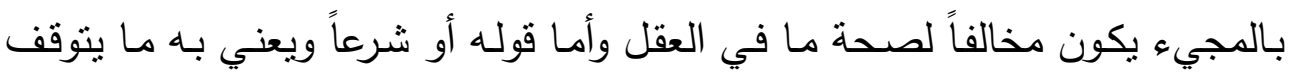

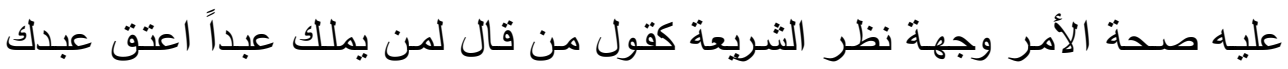

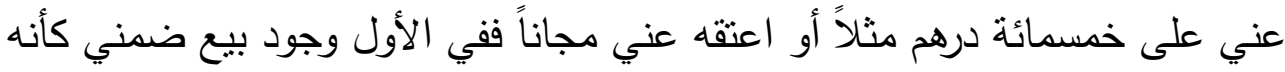

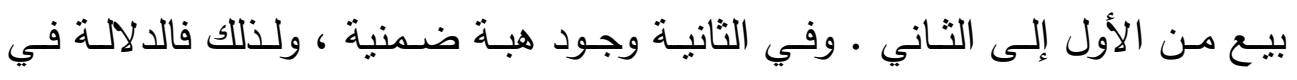


الحالات الثلاث المتقدمة تسمى دلالة اقتضاء (') لأنها تقتضي شيئًاً آخر مضافاً على الثيء الأول وزائداً على معنى اللفظ الأول .

أمـا دلالـة الإثـارة فتعني انـه إن لـم يكن المعنى المستفاد من اللفظ مقصسوداً

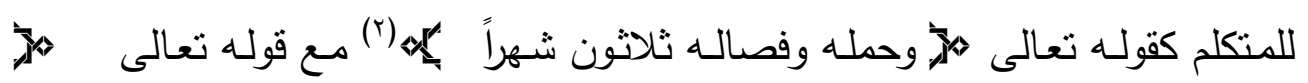
وفصاله في عامين بمها () فيترتب على هذا أن أوجز مدة لحمل المرأة ستة أشـهر ولا

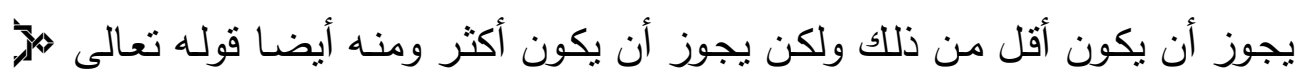
أحلَّ لكم ليلة الصيام الرفث إلى نساءكم بهيه (๕) فانه بلزم منه جواز الإصباح نجساً. أما دلالة التتبيه فإن لم يتوقف اللفظ على شيء بقدر واقترن بحكم لو لم يكن

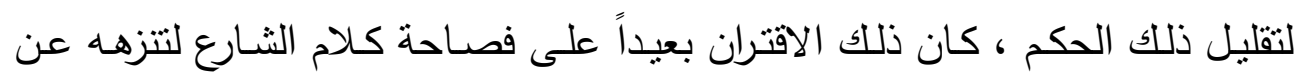
الزيـادة التي لا فائدة تحتهـا في كلامهم ولذللك تسـى دلالـة التتبيـه دلالــة إيمـاء ، والإيماء إثارة ومنه قولنا أومأ فلان إلى صديقه بمعنى أثنار إليه . وسبق أن عرفنا المفهوم وذكرنا ما يقابله عند النحوبين واشتراط تحقق المفهومية من وراء المنطوق ، وإذا كان المفهوم في الأصل هو كل ما يفهم من نطق أو غيره فهو ما يستتد إلى المنطوق ولكنه مفهوم من غير تصريح بالتعبير عنه بل له ارتكاز

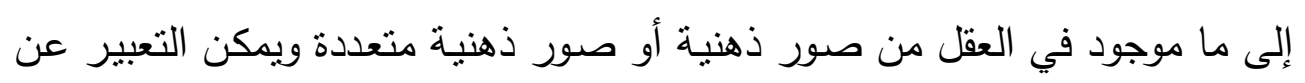
معانيها عن طريق النطق بالألفاظ والجمل والتراكيب ، وينقسم المفهوم إلى نوعين : مفهوم موافقة (') وهو الذي وافق السكوت عنـه المنطوق في الحكم فيسمى مفهوم

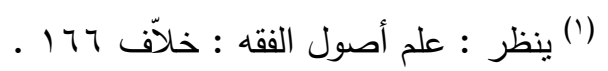

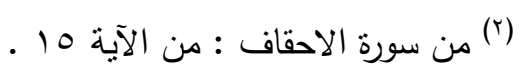

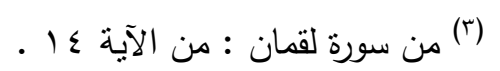

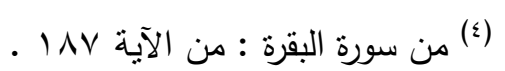

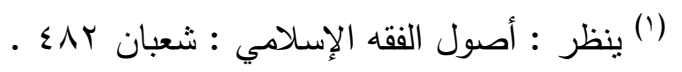


موافقة ويسمى فحوى الخطاب ولحنه أب لحن الخطاب ؛ ولحن الخطاب هو ما يلوح

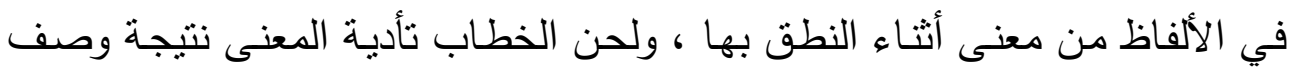

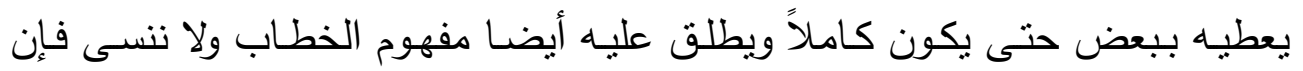

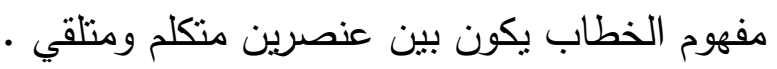

ومفهوم الموافقة قسمان : قطعي وضني ، فالقطعي يتمثل برهن مصحف أو أي أي

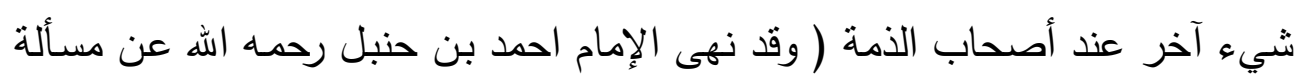

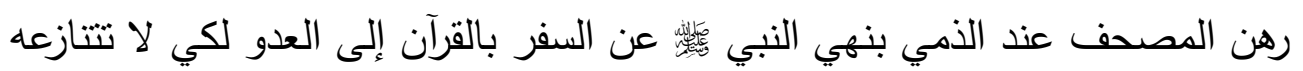

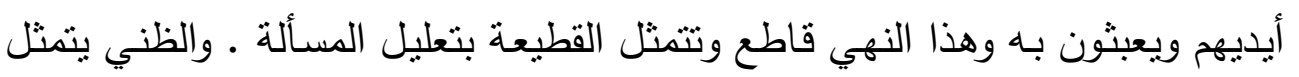
برد شهادة الفاسق ولو استجرت بشهادة الكافر كان أولى برد شهادته لأن الكفر فيه بهانه

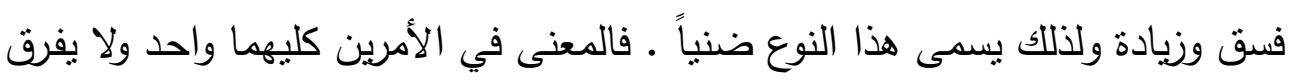

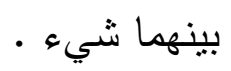

أمسا مفهوم المخالفة فعلى ستة أقسام (؟): فمفهوم صفة وتقسيم وشرط وغايـة

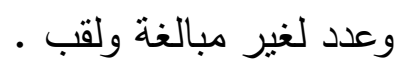
أما مفهوم الصفة فهو أن يقترن بعام صفة ك ( في الغنم السائمة زكاة ) ولذلك الكاء

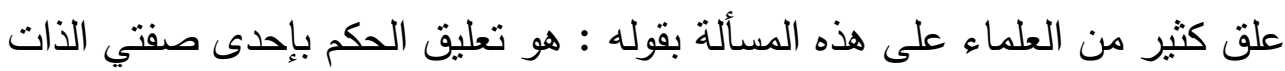

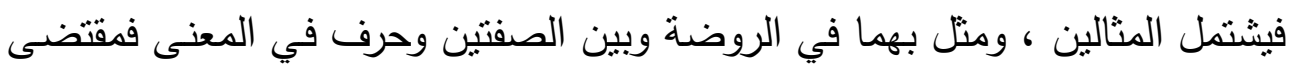

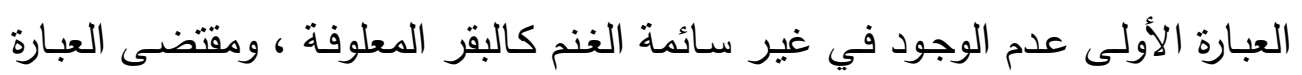

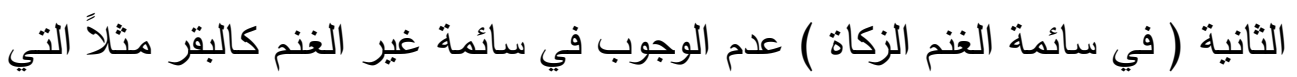

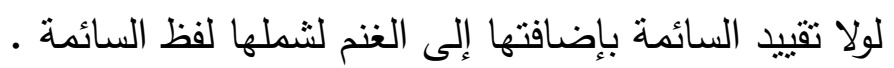


أما مفهوم التقسيم : فهو كقول القائل : ( الثيب أحق بنفسها والبكر تستأذن ) وهو كالأول من حيث القوة وتوجيه ذللك أن تقسيمه إلى قسمين وتخصيص كل واحد

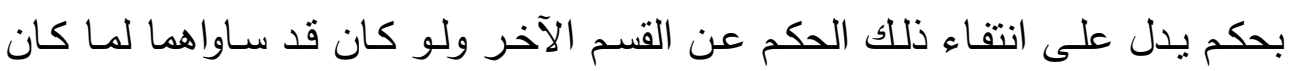

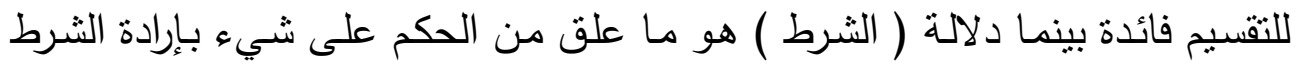

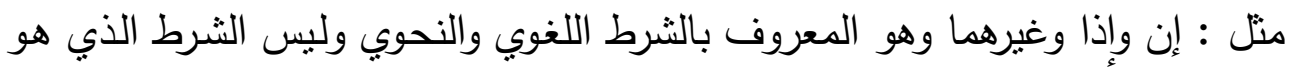

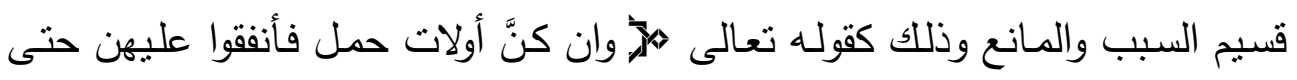

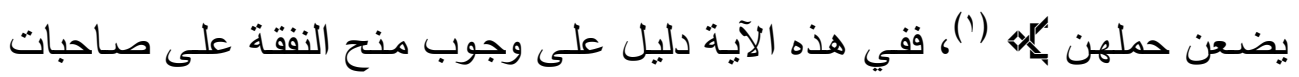

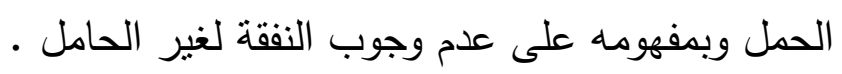

أمسا دلالة الغاية فهو حد الحكم بأداة تعبر عن الغاية ، وتؤدي وظيفة الغاية

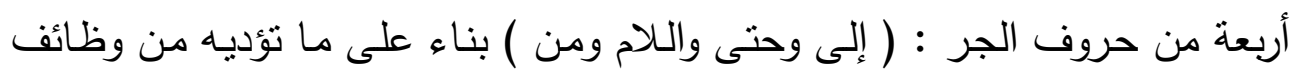

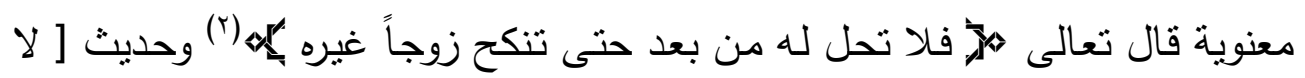

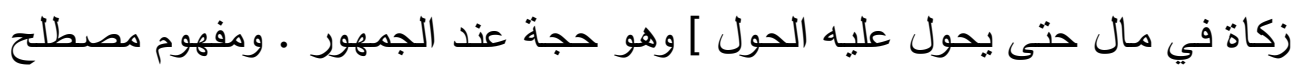

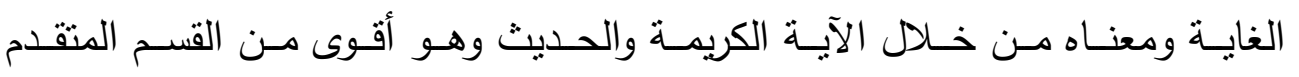

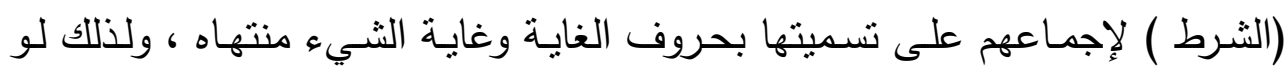

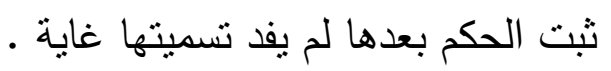

ومفهوم العدد : وهو تعليق الحكم بعدد مخصوص أب يجب الالتزام بـه لأنه

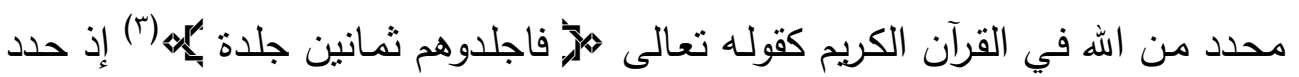

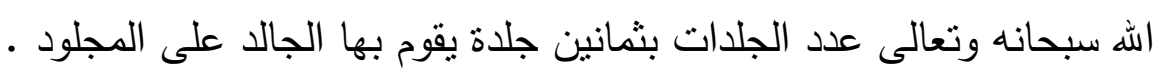

(1) من سورة الطلاق : من الآية 7 .

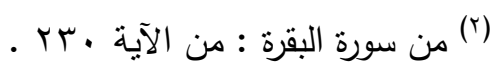

(ז) من سورة النور : من الآية ؛ ـ من الآية 
والقسم الأخير اللقب : ويعني تخصيص اسم بحكم وهو حجة ومنه قول النبي

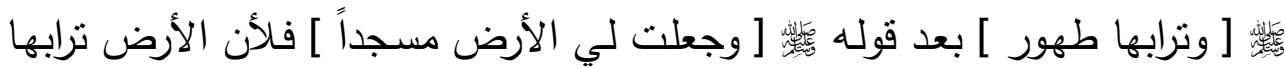

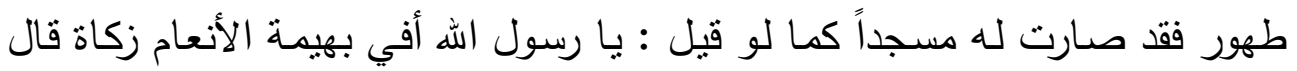

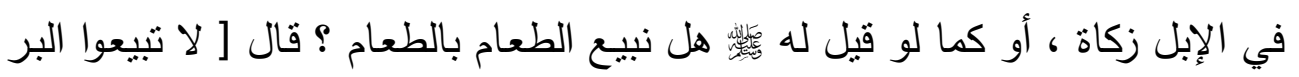

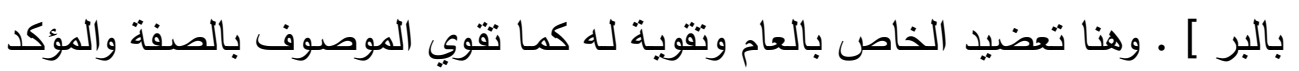

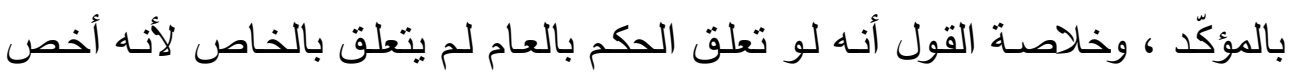

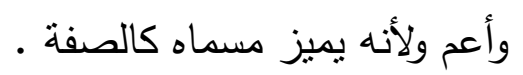
الفصل الثالث التخصيص : أركانه و أقسامه

يجب في باب التخصيص أن تتوافر عوامل أو حدود ثلاثة هي حصيلة معادلة

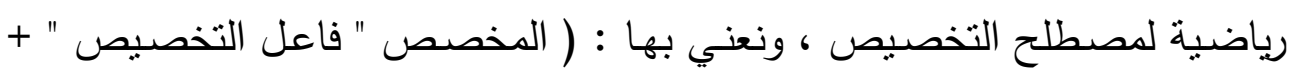

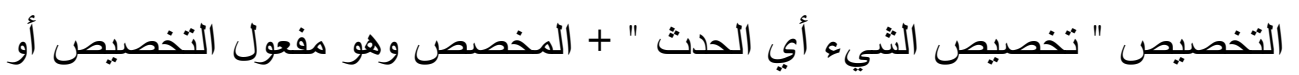

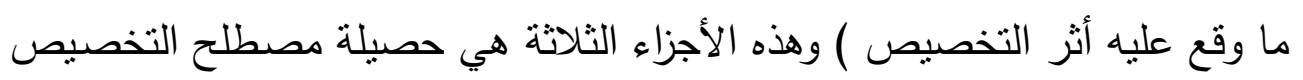

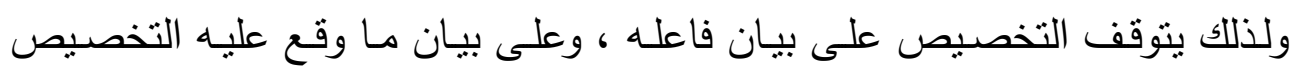

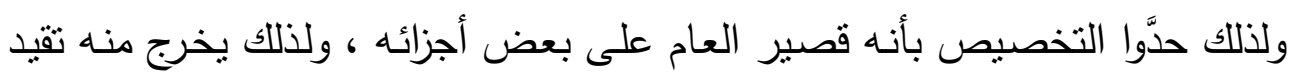

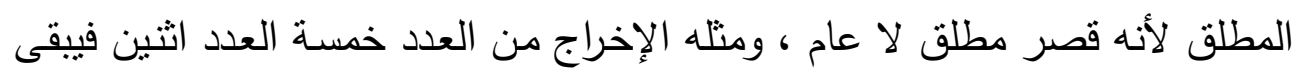

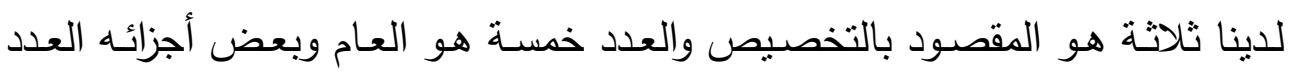
اثثين ومثلك كعشرة إلا ثلاثة ، فالتخصيص يتوجه إلى العدد سبعة ويدخل فيه ما يشير ظاهره إلى عموم اللفظ كقول من فال : ( اقتلوا المشركين ) إذ إن فيه قصراً بالداليل

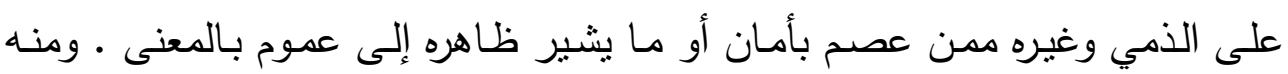

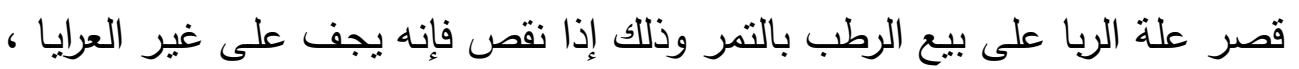

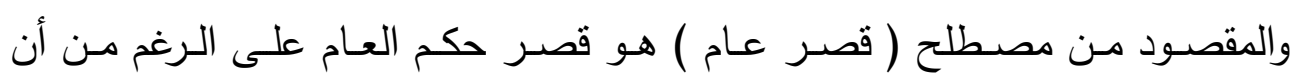
مصطلح العام يبقى مشيراً إلى عموميته ولكن هذه العمومية تكون باللفظ وليس بالحئ الحكم 
، ومن هنا يتوضح الفرق بين اصطلاح ( العام ) وإرادة ( الخاص ) فإن ذلك قصر

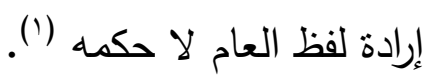

\section{التخصيص}

أوضحنا فيما تقدم إن الدخصص بتضعيف الصاد الأولى مع الكسر هو حقيقة لأنه هو الفاعل الحقيقي للتخصيص أي هو الذي يقوم بالتخصيص الذي هو الإخراج

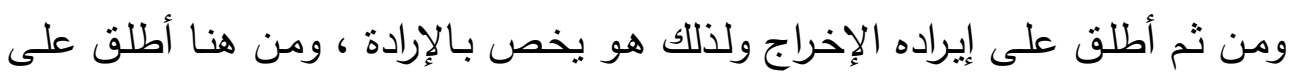

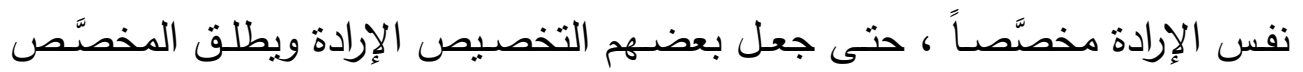

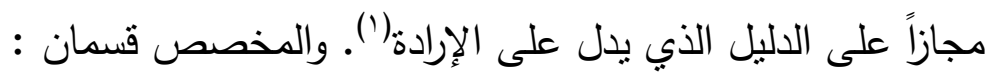

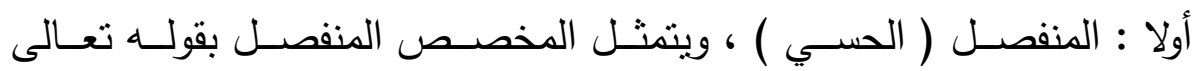

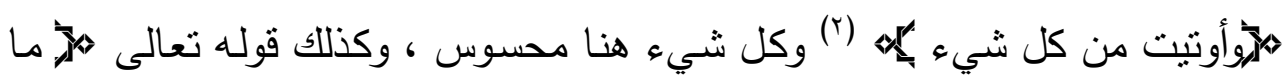

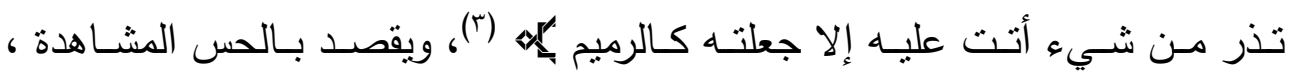
والمشاهدة لما يدرك في العالم الخارجي • وإذا كان الحسيُ جزء من المنفصل فئه فيقابله العقلي ويقسم على قسمين (\&):

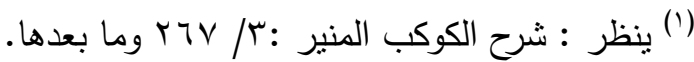

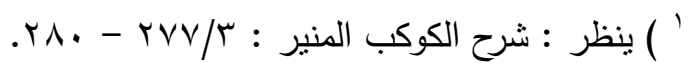

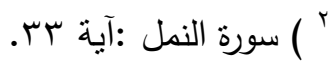

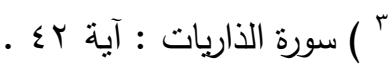

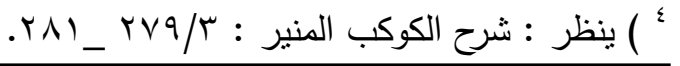


د. عمـــران الطـــــويل

الدرس اللغوى فى شرح الكوكب المنير

أ . ضـروري : وجعل عليه قوله تعالى هالَّ الله خالق كل شيء بيكه (') فالعقل

يقتضي بالضـرورة أن الهه لم يخلق نفسـه وهذه تقابلها آيات تجسد هذا المفهوم منها

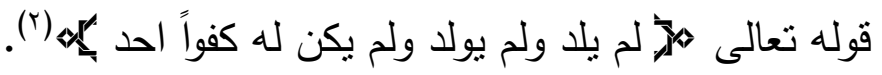

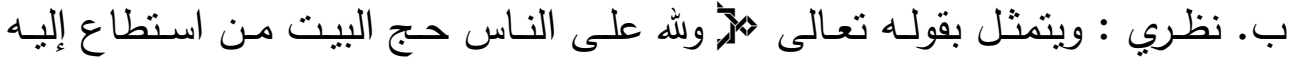
سبيلا بـامها (r) فالعقل بناء على مفاهيم ثابتة مستقرة اقتضى عدم شمول كل من الطفل والمجنون بالحج لعدم إدراكهما الكامل وعدم استطاعتهما عقلاً وقصور كل منهما ـ ولذلك هما مع الذين لا يقصدهم الله سبحانه في خطابه بالآية الكريمة

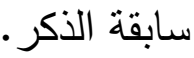

ثانيا ـ المتصل بعني أنه هو الذي يتبع كلاماً متقدماً ، وهو جزء منه فيكون من جنس المتقدم وليس منقطعاً عنه ، والمتصل بشمل أقساما متعددة : ا ـ استثناء متصل : فالاستثناء مأخوذ من الثي ، والثتي يعني العطف لأنك تقول ثثيت رجلي ثثيةً إذا جعلت بعضها على بعض ، وقيل هو من ثثيته عن الثيء أي انصرافه (') (والاستثناء المتصل هو إخراج جزء من كل لعله في المعنى، ولولا وجود الاستثناء لما فهم المعنى المطلوب ، فحين تقول : ( حضر الملأ إلا هوب هري زيـداً ) فلـو سـط الاسـتثناء لمـا فهم خـروج زيــ مـن المـلأ ولـللك ليس بجـائز الاستثناء مما هو نكرة إذ لا يصـح إخراج معرفة من نكرة وعلى هذا لا يقال : جـاءني قوم إلا محمداً ، إذ يحتمـل إن غايـة المـتكلم ليسـت دخول محمد حتى إهى

' ) سورة الإنعام : من الآية . ^ ، سورة الأعراف : من الآية 9 ، ، سورة طه : آية ^ه9 ، سورة

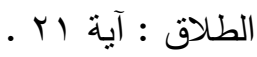

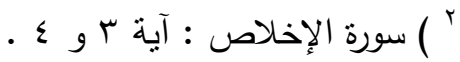
.

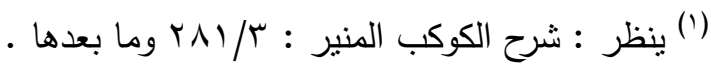


يخرجه ـ ولذلك يقتضي أن يكون المستثى منه ( الطرف الأول ) عام والمستثى

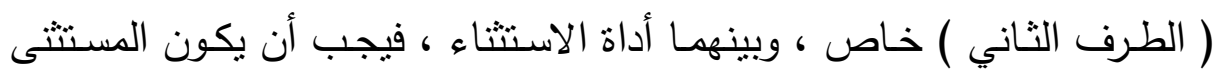
منه والمستثنى من جنس واحد ، وقيل إن الاستثناء هو عملية إخراج ما لولاه لجاز دخوله ) (r) أما شروط تحقق صحة الاستثناء فتتوضح في كون المستثى صـادراً من متكلم

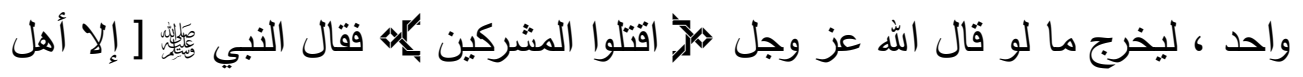

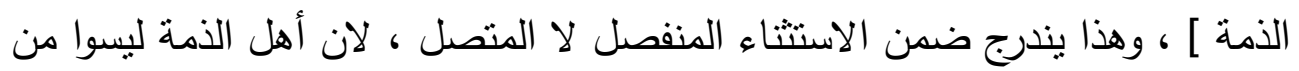

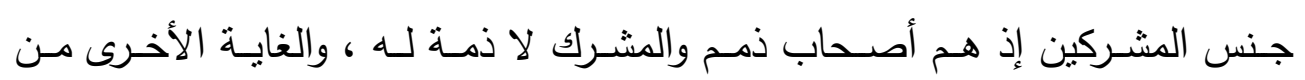

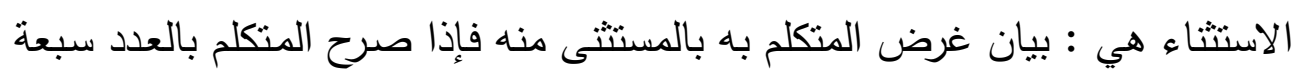

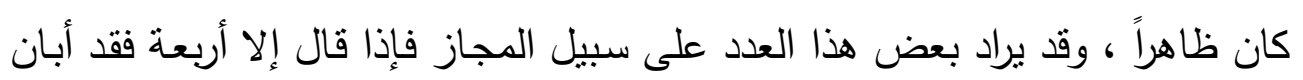
عن أن مطلبه بالسبعة ثلاثة فقط ، ولذلك خصص من من بين أجزاء العدد سبعة ثلاثة

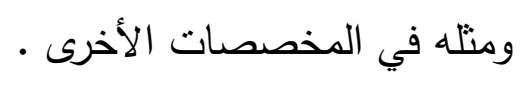

أما أنواع الاستثناء فقد حدت بأربعة أنواع ('):

الأولى : ما لولاه لعلم دخوله ويستمد من الأمتلة المتقدمة ومنه أيضا : لله ستة إلا أربعة ، والمقصود لولا ذكر الأربعة لعلم دخول الستة كلها ـ لاهل

الثاني : ما لولاه دخوله كالاستثناء ما هو ظاهر ، ومنه قولنا اقتلوا المشركين إلا زيداً ، لان زيداً لم يقع عليه حد القتل ولو لم يذكر لجاز وقوع الحكم عليه ولكنه

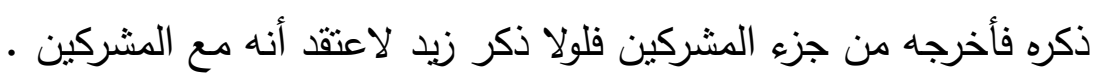

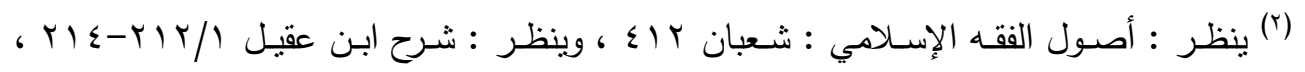

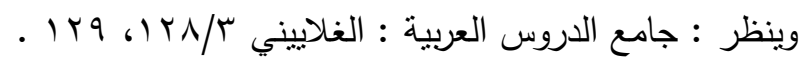

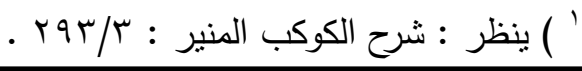


د. عدـــران الطــــــيل

الدرس اللغوى فى شرح الكوكب المنير

الثالث : مـا لولاه لجـاز دخولـه : كالاستثناء مـن المحسال والأزمـان والأحوال

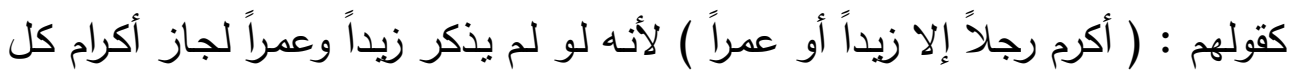

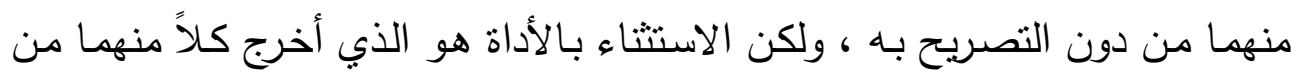

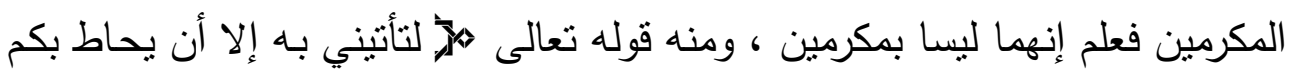

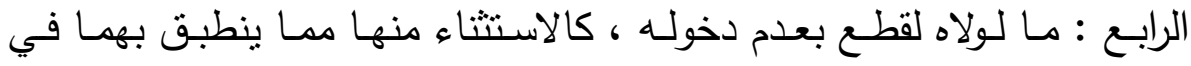

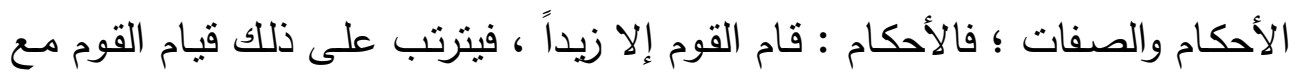

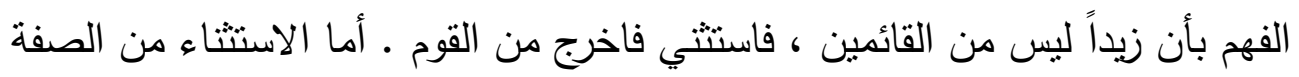

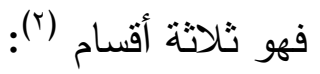

أ ـ من متعلقها كقول الثاعر : قاتل ابنة البتول إلا علياً ، لأن الصفة متعلقة بالتبتل

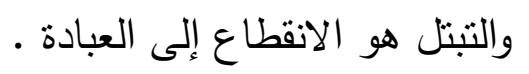

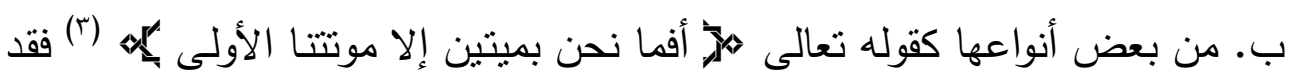

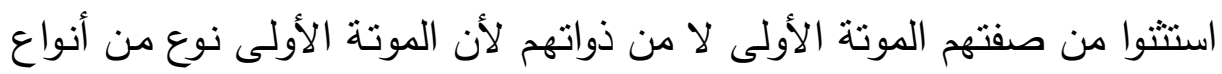

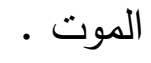

ج • إن يستنثى بجملتها ولا يترك شيء منها كقولهم : أنت طالق أنت طالق طلقة واحدة إلا واحدة ، والثمانبة الباقية لا ينطبق بها ويقع الاستثناء منها : الأسباب ، كقولهم : لا عقوبة إلا بجناية بمعنى إن لم تحصل الجناية

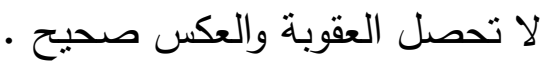


الثروط ، كقولهم : لا صلاة إلا بطهور · فإذا لم يكن العبد طاهراً لا

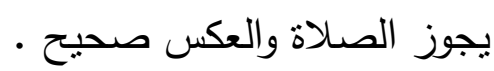

الموانع ، كقولهم : لا تسقط الصـلاة عن المرأة إلا بالحيض ، فصـار

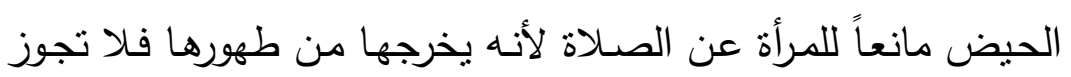

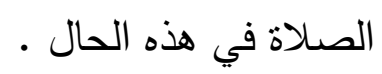

الهحال ، كقولهم : أكرم رجلاً إلا زيداً أو عمراً وبكراً ، فإن كل شخص الهص هو محل الاعمية .

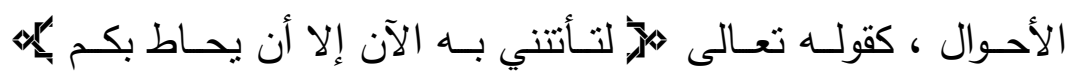
(1) والكقصود : لتأتينني به في الأحوال كلها إلا في حال الإحاطة فإنكم معذورون - مال

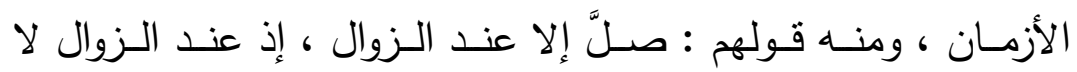
يصلى.

الأمكنة ، نحو : صلّ إلا عند المزبلة ونحوها لعدم طهور أرضها .

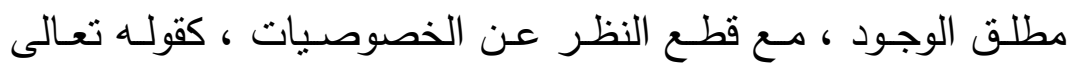

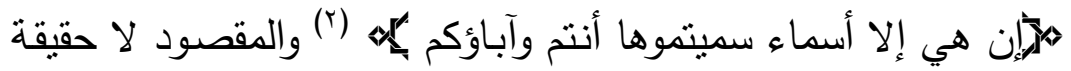
الأصنام مطلقاً إلا أنها لفظ مجرد ، فاستثني اللفظ من مطلق الوجود التهاء

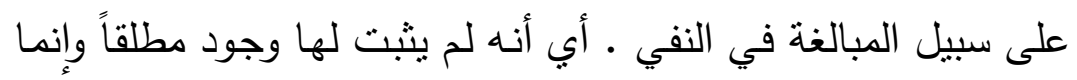

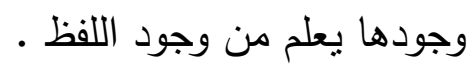

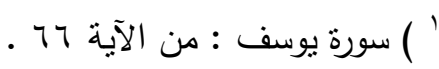

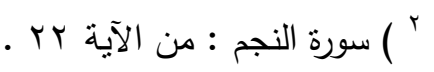


وهذه الثروط الثمانية لم ينكروا وقوع الاستثناء فيها ، إنما الاستثناء تعلم بما يذكر بعد أداة الاستثناء ـ أما شروط الاستثناء فهو إما أن يكون الاتصال المعتاد لفظاً

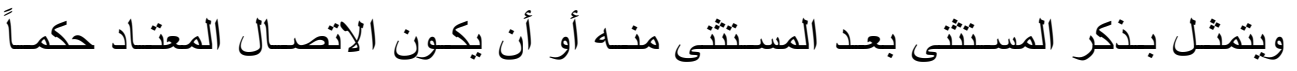
كانقطاعه عنه يتنفس أو غير ذلك أو نية الاستثناء والمقصود بـه أن ينوي المستثنى قبل تمام المستثتى منه أو النطق بـه والمقصود النطق بالمستثتي إلا في يمين خائف ينطقه ولا يشترط في الاستثناء ، وتأخير المستثى عن المستثى منه في اللفظ فيجوز

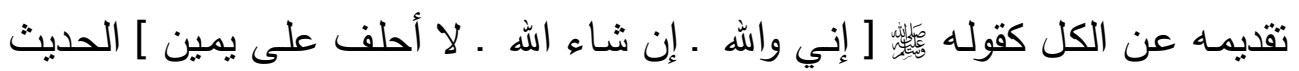
متفق عليه • ويستثى بصفة مجهول من معلوم ومجهول من مجهول والجميع ، كاقتل

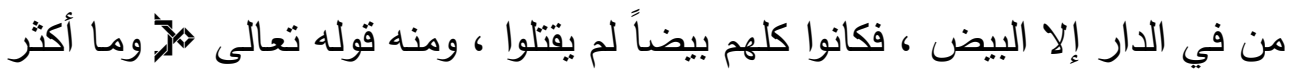
الناس ولو حرصت بمؤمنين بها ( (') فهذا تخصيص بصفة ويستثى بالصفة مجهول من معلوم ومن معلوم ومن مجهول ويستثنى الجميع أيضا ـ فلو قال : اقتل من في الدار إلا بني تميم ، أو البيض فكانوا كلهم بني تميم أو كانوا كلهم بيضاً لم يجز قتلهم

r. الثرط : ويعد من المخصص المتصل ويختص الثرط اللغوي من الثرط المطلق لأن الثرط اللغوي مخصنص ، أي أن هنالك شرطين : شرطاً مطلقاً يندرج تحته شرط لغوي(ץ). على حين لا يرى النحويون ما يراه مؤلف الكتاب ، إذ إن الثرط يقتضي توافر ( الأداة + فعل الثرط + جواب الثرط ) والجملة الثرطية جملة عقلية ، لان الثاني متعلق بـالأول والأول يحصل بحصول الثاني ، فإذا قلنا إذا قام عمرو قام زبد ـ فإن قيام زبد لا يحصل إلا بقيام عمر فمتى قام عمرو قام

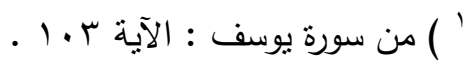

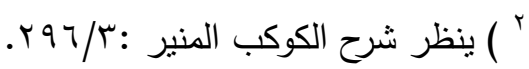

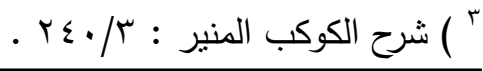


زيد ، ولذلك يعد أسلوب الثرط أسلوباً عقلياً وهو خلاف على ما يراه صاحبنا وليس جزء من المخصص المنصل('). ومن هنا افترق الأصوليون عن النحوبين في مسألة الثرط فالأصوليون يعلقونه بالمخصص المتصل والنحوبون يجعلونه

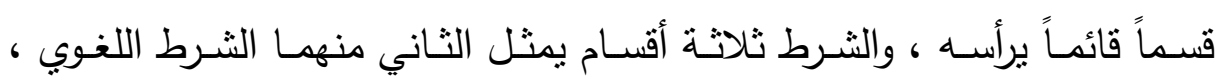

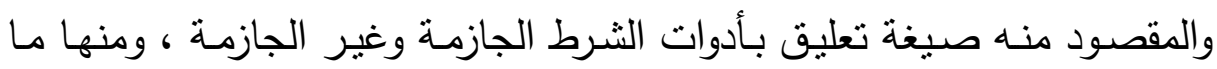
يذكر في أصول الفقه من المخصصسات للعدوم كقوله تعالى هالَّ وان كنّ أولات حمل فانفقوا عليهن بيمه (r) والشرط مخرج ما لولا الشرط لدخل ذلك المخرج كقول القائل : ( أكرم بني تميم إن دخلوا ) أب أن الإكرام يخص الداخلين من بني تميم ولكنه لا يخص بني تميم كلهم لأنهم لم يدخلوا كلهم و ( إن ) هنا شكية لا يقينية فقصر الشرط على من دخل لا على من لم يدخل ، وقد يتحد الثرط في قول من قال : ( إن دخل زيداً الدار فأكرمه وأعطه أو فأكرمه أو أعطه ) والمقصود أن لن لأن الإكرام يحصل بعد دخول الدار ، ولكن زيداً لم يدخل الدار إلى الآن ، والقصد باتحاد الشرط أن الإكرام يحصل بعد تحقق الدخول فمتى ما تحقق الدخول تحقق الإكرام وإن انتفى الدخول انتفى الإكرام ، وقد يعدد الثرط على الجمع بين حدين

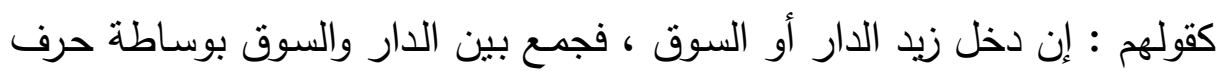
العطف الواو كذلك يتعدد الثـرط على البدل كقولهم : إن دخل زيد الدار أو السوق فهو لم يـخل المكانين وإنمـا يـخل الدار أو يـخل السوق ـ فهذا أفـاد البداية في المكان وقد عنوا بمسألة البدل : دخول زبد الدار بدل السوق أو السوق بدل الدار ، فهذه ثلاثة أقسام وكل من هذه الأقسام مع الجزاء كالثرط ، يعني أن الجزاء ( يقصد بالجزاء جواب الثرط ) إما أن يكون متحداً أو متعدداً على سبيل 


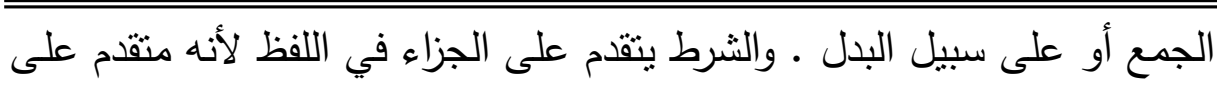

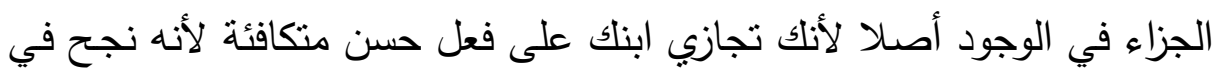
الددرسة وتكافئه لأنه يريح بالك ـ والجمل في أسلوب الثرط تتألف من ( أداة

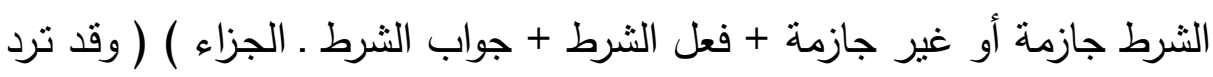

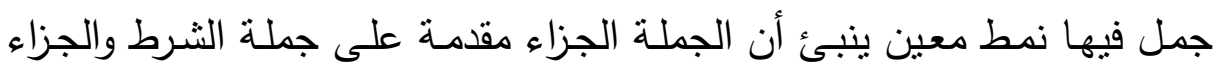

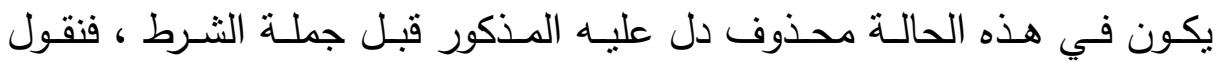

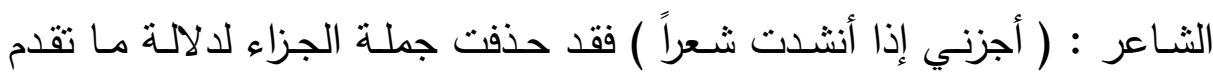

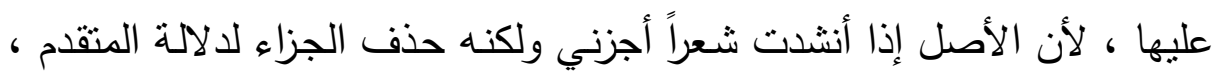

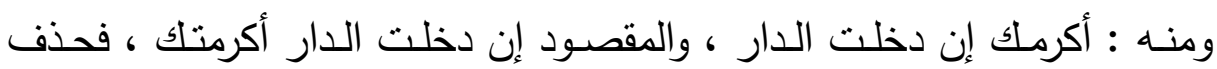
جواب الثرط ( الجزاء ) لدلالة ما تقدم عليه وذلك كثير في العربية ) ('). r. الصفة : وتعد من المخصص المنصل مثلها مثل الثرط ، والصفة تعني : مـا

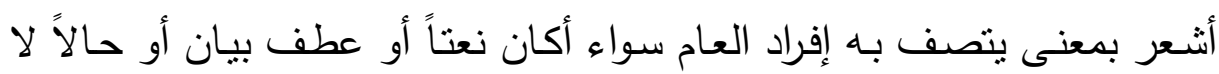

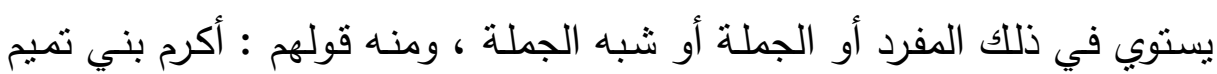
الداخلين ، فقصر الإكرام عليهم (؟). ع. الغاية : وهي من المخصص المتصل أيضا والمراد بالغاية أن برد بعد اللفظ العام

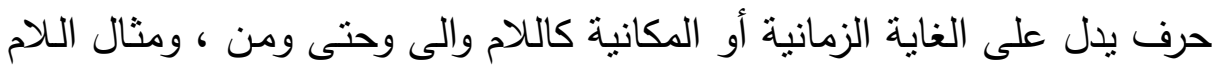

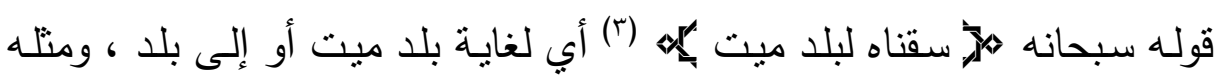

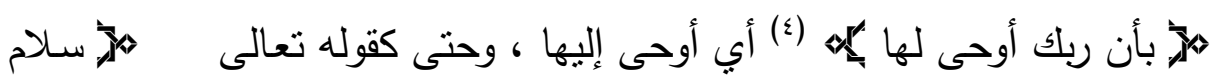




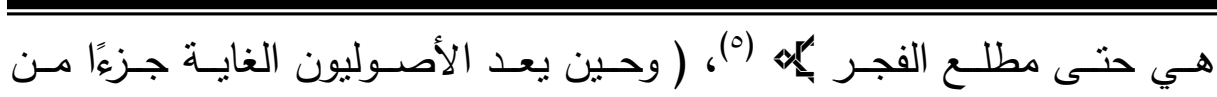

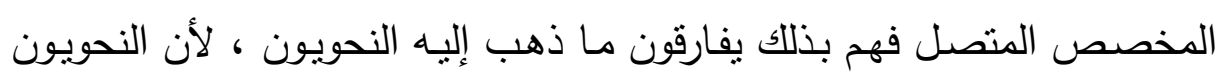

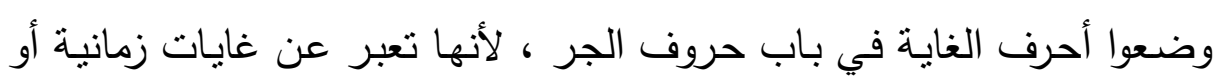

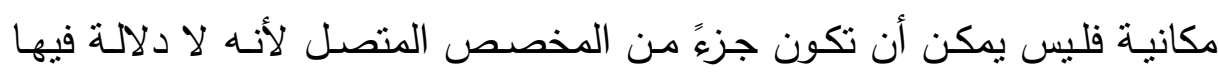
وتللك نقطة فارقة بين وجهة نظر الجماعتين )(").

مما يعد حرف الغاية مخالف لما قبله أبي محكوم عليه بنقض حكمه لأن ما لما

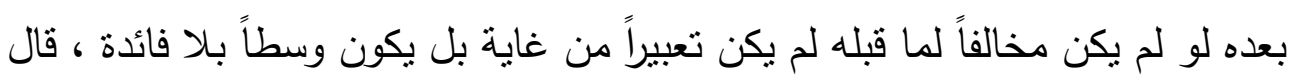

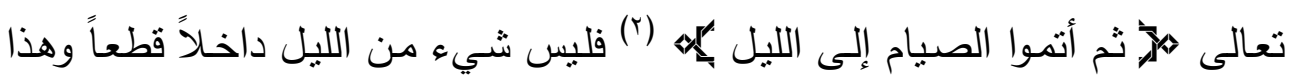
متفق عليه عند الجمهور وقبل أن تميزه عنا قبله بالحسن لم يدخل وإلا دخل والمتميز

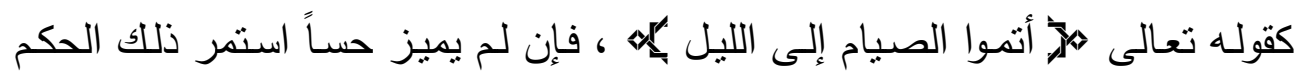

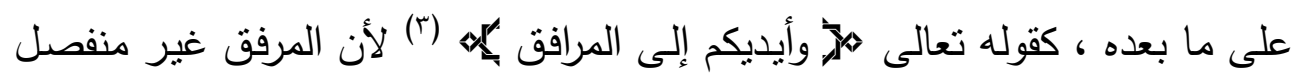

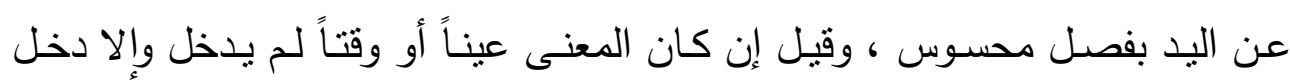

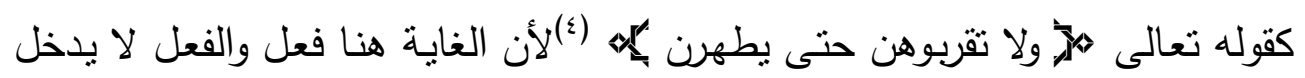

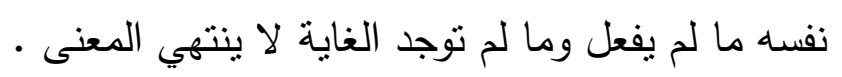

ه. بـل البعض : وهو أيضـا عند الأصوليين من المخصص المتصل كقولهم أكرم

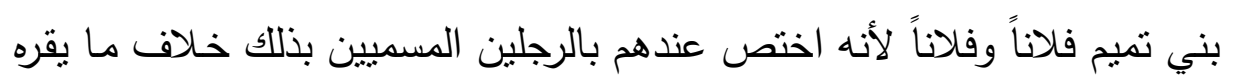

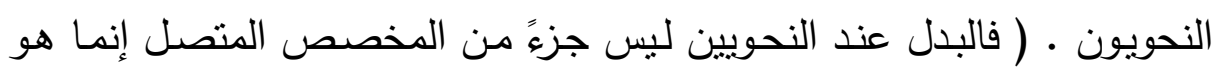

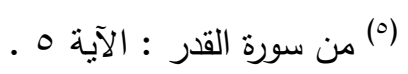

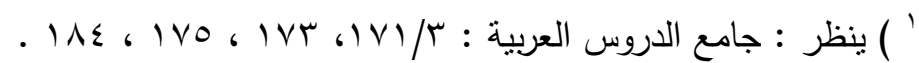

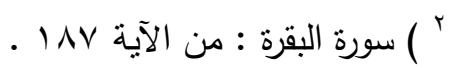

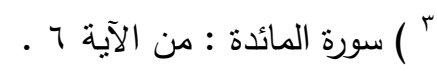

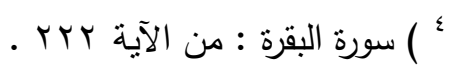

$\varepsilon 7$. 
د. عمـــران الطـــــويل

الدرس اللغوى فى شرح الكوكب المنير

باب نحوي منفرد عن باقي الأبواب شأنه شأن بقية الأبواب ـ فحين تقول : أكلت

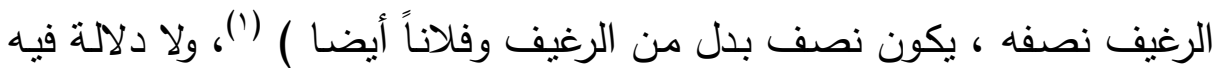

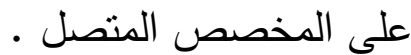
الخاتمــــــة

يمكن إيجاز أبرز ما تعرّض له البحث وأهم النتائج التي تمخّض عنها في سيره

$$
\text { بالآتي نصه : }
$$

1. تتاول ابن النجار معظم القضايا اللغوية التي تتاولها الأصوليون من قبله وبيّن

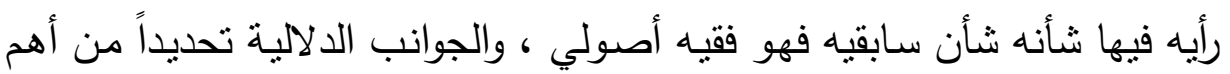
الجوانب التي يقوم عليها علم أصول الفقه لفهم النصوص واستتباط الأحكام

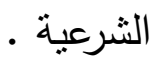

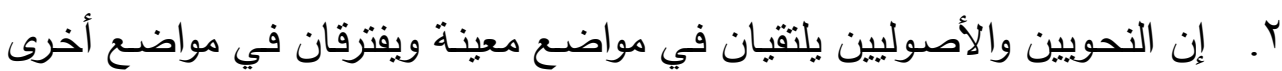

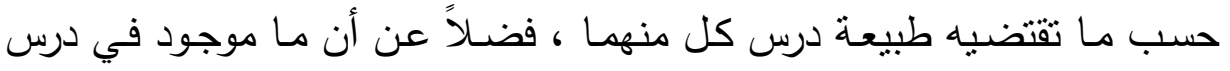

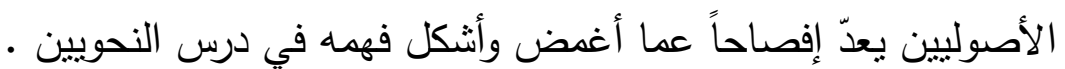
r. اختلاف وجهة نظر كل من اللغويين والأصوليين في مسألة الألفاظ وتقسيمها إلى مترادفة ومتواردة ـ واتفاقهم على تقسيم اللفظ إلى مهمل ومستعمل ـ وهي حقيقة

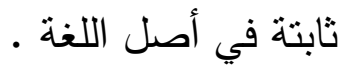
ع. اختلاف الأصوليين عن النحويين في حقيقة ( المركب ) في الدرس اللغوي . ๑. إن الاعتباط هو مرحلة متوسطة تعبر عن العلاقة بين الدال والمدلول وهو إطلاق

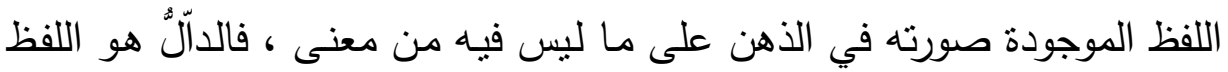


والمدلول هو المتعارف عليه ـ والاعتباط هو علاقة اللفظ بالمعنى على ما قاله دي سوسير ( rاو (م ) وهذا ما أوضحه ابن النجار وغيره قبله بمئات القرون. 7. إن الدلالة المطلقة ثلاثة أنواع دلالة وضعية ودلالة لفظية ودلالة عقلية ، وهذه الدلالات تتأرجح بين الحقيقة والمجاز إذا ما أراد المتكلم غاية في كلامه فبين عن ودهاع مراده ، وقد أوضحنا ذلك في البحث ، فضلاً عن تقرع أنواع لهذه الدلالات تتدرج تحتها وتكون العلاقة بينها وبين أصلها علاقة العام بالخاص . V. ذكر ابن النجار الفرق القائم بين دلالـة اللفظ والدلالـة بـاللفظ ، وبينين أن دلالة اللفظ هي الدلالمة المتعـارف عليها من استعمال هذا اللفظ على وجـه الحقيقة ، بينما الدلالة باللفظ هي الدلالة التي يفرضها الاستعمال الذي يلجأ إليه المنشئ ويفرضها المتلقي في العملية الخطابية ، فوضّتح بذلك أثر الاستعمال في تحديد دلالة اللفظ إذ لا يمكن أن توصف الألفاظ بأنها حقيقية أو مجازية إلا من خلال فله بله

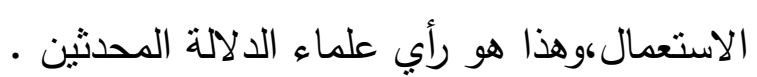
^. إن ابن النجار من القائلين بوقوع الترادف في اللغة وذكر بأنه إقامة لفظ مقام لفظ لمعان منقاربة . 9. إن المنطوق والمفهوم في درس الأصوليين يقابله اللفظ والمعنى في درس اللغوبين

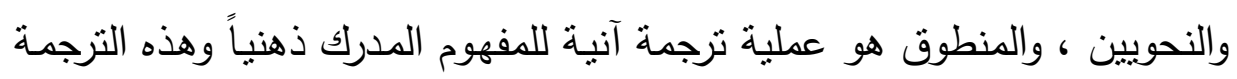
الآنية هي توافق بين الذهن واللسان لتحويل المعنوي المدرك أي محسوس معروف

إن هذا البحث ـ في الحقيقة ـ قد منح الباحث فرصة التعرف على بعض ما في درس الأصوليين فيما يخص جانب الهه ، وقد أودعنا فيه ما وسعنا من جهد ، ونبتغي من الله التوفيق والسداد ، وآخر دعوانا أن الحمد لله رب العالمين والصلاة والسلام على نبينا محمد بن عبد الله ، واستغفر الله لي ولكم . 


$$
\text { الم المصادر و المر اجع الكريم. }
$$

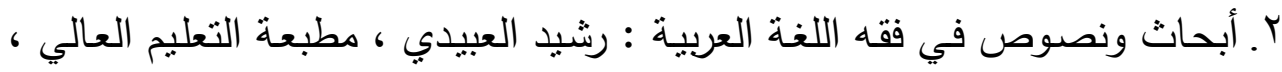

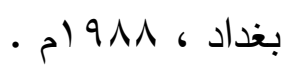

r. الإحكام في أصول الأحكام : سيف الدين أبو الحسن علي بن محمد الآمدي ، دار

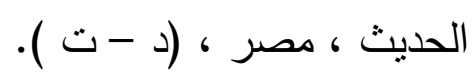

ء. إرشـاد الفحول إلى تحقيق الحق من علم الأصسول : محمد بن علي الثوكاني ،

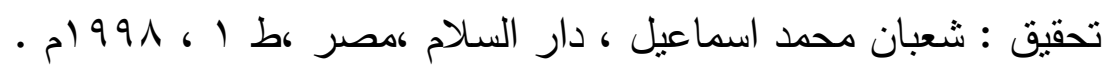

๑. أصول الفقه الإسلامي : بدران أبو العينين بدران ، مطبعة م. ك . ، الإسكندرية (

$$
\text { . ( ) }
$$

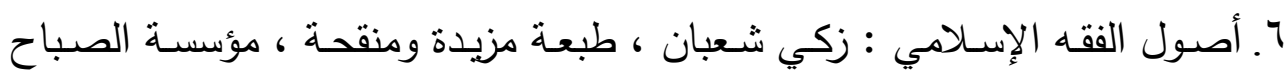

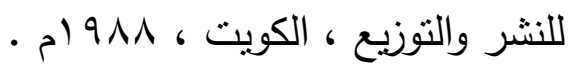

V. تحرير القواعد المنطقية لقطب الدين محمود بن محمد الرازي وهو شرح للرسالة

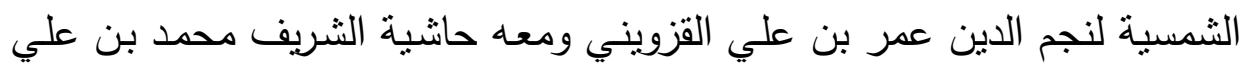

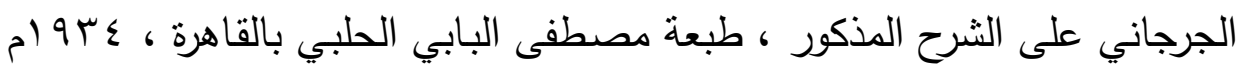


^. الترادف في القرآن الكريم بين النظريـة والتطبيق :محمد نور الدين المنجد ، دار

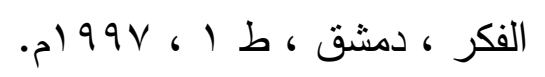

9 9. التعربفات : الثربف الجرجاني ، الدار التونسية لنشر ، ( د ت ) . • 1. جامع الدروس العربية : مصطفى الغلاييني / طسץ ، راجعهـ ونقحه د. عبد المنعم خفاجة ، المكتبة العصرية ، بيروت ، 919 ام ـ ل

1 ا. الخصائص : ابن جني ، طץ ، حققه محمد علي النجار ، دار الهدى للطباعة

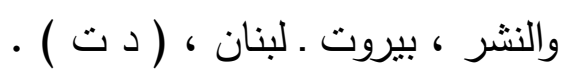

r ا. شرح ابن عقيل : ابن عقيل ، طץ ، تحقيق / محمد محي الدين عبد الحميد ،

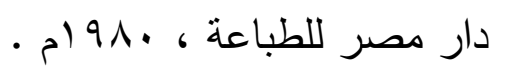

سا. شرح تتقيح الفصول :الإمام شهاب الدين أبو العباس أحمد بن إدريس القرافي ، تحقيق : طه عبد الرؤوف سعدطط ا ، نشر مكتبة الكليات الأزهربة ودار الفكر

$$
\text { - ) } 9 \vee r
$$

ع ا. الصاحبي في فقه اللغة وسنن العرب في كلامها : احمد بن فارس ، حققه وقدم له / مصطفى الثويحي ، مؤسسة أ. بدران للطباعة والنشر ، بيروت ـ لبنان ،

$$
\text { - }) 97 \varepsilon
$$

10. علم أصول الفقه وخلاصة تاريخ التشريع الإسلامي : عبد الوهاب خلاف ، طس

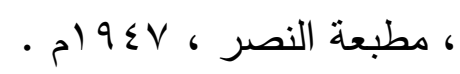

جا ا. علم الدلالة : احمد مختار عمر ، طا ، مكتبة دار العروبـة للنشر والتوزبع ،

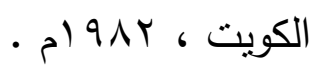

V V . علم اللغـة ( مقدمـة للقارئ العربي ) : محمود السعران ، دار النهضـة العربيـة للطباعة والنشر ، بيروت ( د ت ) . 
د. عمـــران الطــــــيل

الدرس اللغوى فى شرح الكوكب المنير

1^. علم اللغة : حاتم الضامن ، طبع بمطبعة التعليم العالي ، الموصل ، 919 ام. 9 1. فتح الرحمن شرح شيخ الإسـام زكريا بن محمد بن أحمد الأنصاري الثـافعي على لقطة العجـان وبلـة الظمآن في فن الأصـول للشيخ محمد بن عبد الله الزركثي الثافعي • وبهامشه حاشية ياسين زين الدين العليمي الحمصي على الثرح المذكور ، طبع مصطفى البابي الحلبي بالقاهرة ، 79 ام. •r. فصول في فقه العربية : رمضان عبد التواب ، طץ ،مكتبة الخانجي ، القاهرة - م) $9 \wedge \mathrm{V} 6$

اب. فقـه اللغـة وخصـائص العربيـة : محمد المبارك ، طه ، دار الفكر ، بيروت ، - p) $9 \vee r$

r r. لسـان العرب : ابن منظور ، دار لسان العرب للنشر والتوزيع ، بيروت ( د ت - (

بr ب. المحصـول في علم أصسول الفقه : فخر الدين الرازي ، دراسـة وتحقيق : طـه جابر فياض العلواني ، مؤسسة الرسالة ، بيروت ، لبنان ، ط ب ، و99 ام . ؟ r. المزهر في علوم اللغة وأنواعها : السيوطي ، شرحه وضبطه وصححه وعنون موضوعاته وعلق حواشيه / محمد احمد جاد المولى ، علي محمد البجاوي ،

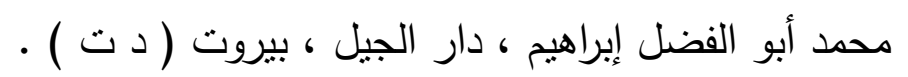
هץ. منهج البحث اللغوي بين التراث وعلم اللغة الحديث : علي زوين ، دار الثئون

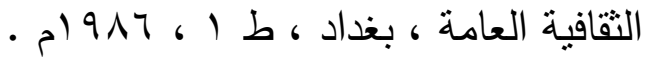
דr. النحو الوافي : عباس حسن ، طب ، دار المعارف بمصر ، ( د ت ) . rV

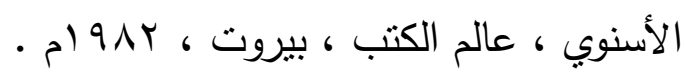




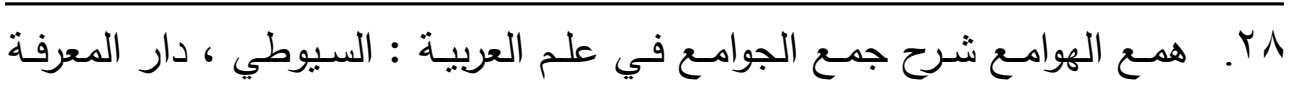

$$
\begin{aligned}
& \text { للطباعة والنشر ، بيروت ـ لبنان ، (د ت ) . }
\end{aligned}
$$

\section{الهرس اللغوى فُى شرح الكوكب المنير}

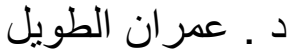

\section{ملخص البحث}

يدور هذا البحث في كتاب مهم من كتب أصول الفقه وهو كتاب (شرح الكوكب

المنير) لمحمد بن أحمد عبد العزيز الفتوحي تقي الدين الثـهير بـ(ابن النجار)،ويتركز

البحث في الدرس اللغوي الموجود في هذا الكتاب، ويوضتح أهميته في كتب الأصول

بشكل عام ،إضافة إلى توضيح اختلاف وجهة نظر كل من اللغوبين والأصوليين في

مسائل لغوية مثل مسألة الألفاظ وتقسيمها واتفاقهم في أخرى .

فهذا البحث يسلط الضوء على ما لدى علماء الأصـول من مباحث لغوبـة في

كتبهم وأهمية دراستها وبحنها .

\section{ABSTRACT}

This research is important in a book of Fiqh wrote a book (enlightening explanation of the planet) for the Mohammed Bin Abdul Aziz Ahmad Afattouhi Taqi Al-Din alias (Ibn Najjar), and the search was focused in the study of language in this book, and illustrates the importance of assets in books in general, In addition to clarify the different point of view of both the language and the fundamentalists on issues such as the question of linguistic terms and their agreement and divided in the other. This research sheds light on what scientists have for the Investigation of assets from their books in the language and the importance of study and consideration. 


\begin{tabular}{|c|c|}
\hline د. عمـــران الطـــــــل & رح الكوكب المنير \\
\hline
\end{tabular}

